\title{
Behavioral Determinants of Proclaimed Support for Environment Protection Policies
}

\author{
Björn Kauder \\ Niklas Potrafke \\ Heinrich Ursprung
}

CESIFO WORKING PAPER NO. 5993

CATEgory 2: Public CHOICE

JULY 2016

An electronic version of the paper may be downloaded

- from the SSRN website: Www.SSRN.com

- from the RePEc website: Www.RePEc.org

- from the CESifo website: www.CESifo-group.org/wp 


\title{
Behavioral Determinants of Proclaimed Support for Environment Protection Policies
}

\begin{abstract}
Using a representative survey of German university students, we confirm that proclaimed support for environment protection policies depends on socio-cultural factors and political ideology. Unlike most related studies for other countries, we find that the environmental policy stance of German partisans does not follow the left-right cleavage. Only about $25 \%$ of the social-democratic partisans wholeheartedly support environment protection policies, whereas $50 \%$ of the green partisans, who, in Germany, also belong to the political left, do so; and when controlling for socio-cultural influences, social-democratic partisans become undistinguishable from Christian-conservative and market-oriented partisans. Focusing on behavioral influences, we find that some of the respondents' psychological traits are not filtered through their political ideology but directly influence their proclaimed attitudes towards environment protection policies. We identify as important behavioral determinants the locus of control and psychological traits that capture the respondents' susceptibility to making use of expressive rhetoric.
\end{abstract}

JEL-Codes: D720, P160, Q510, Q580.

Keywords: environment protection, political preferences, ideology, identity, expressive behavior.

Björn Kauder

Ifo Institute - Leibniz Institute for

Economic Research

at the University of Munich

Poschingerstrasse 5

Germany-81679 Munich

kauder@ifo.de
Niklas Potrafke

Ifo Institute - Leibniz Institute for

Economic Research

at the University of Munich

Poschingerstrasse 5

Germany-81679 Munich

potrafke@ifo.de

Heinrich Ursprung

University of Konstanz

Department of Economics

Box 138

Germany - 78457 Konstanz

heinrich.ursprung@uni-konstanz.de 


\section{Introduction}

The economic literature on environmental policy attitudes has traditionally focused on aggregate socio-economic determinants. In this study we shift the perspective from the aggregate to the individual level and, even more, to the mindset of the individual. We are in particular interested in whether attitudes towards environmental protection policies depend mainly on ideas, as famously claimed by Keynes, ${ }^{1}$ or rather on economic interest and social imprinting, as maintained by traditional political economists and political sociologists.

To investigate the determinants of expressed political support for environment protection policies, we use a comprehensive survey of German students and explore in a first step how the students' environmental attitudes depend on their political ideology. Since political ideologies, apart from abstract ideas, also reflect economic interests and social background, the traditional approach of regressing specific policy attitudes on an individual's political ideology and his or her socio-economic characteristics is a rather weak strategy for identifying the influence of "ideas and identity".

In an attempt to make some progress in identifying deep-set behavioral influences on political rhetoric, we supplement the set of ideology variables by including psychological traits as determinants of individual support for environmental protection policies. The rationale for this identification strategy is that psychological traits strongly affect a person's identity and ideas but portray characteristics that are more persistent and more deeply rooted than attachment to some ideology or political party. ${ }^{2}$ Indeed, we find that psychological traits contribute to explaining the respondents' proclaimed environmental attitudes even when controlling for the respondents' political ideologies and socio-economic characteristics. This

\footnotetext{
${ }^{1}$ J. M. Keynes, The general theory of employment, interest and money (1936), chapter 24, part V: “The power of vested interests is vastly exaggerated compared with the gradual encroachment of ideas.”

2 The literature that explores how personality traits influence political attitudes and ideologies is well developed. Gerber et al. (2010) show, for example, that the Big Five personality traits affect ideology as well as economic and social policy attitudes (see also Gerber et al. 2011). Galais and Blais (2016) explicitly address the causality issue and find that a sense of duty has a significant causal effect on voter turnout.
} 
finding lends support to the hypothesis that the voters' identities and ideas are an independent determinant of their proclaimed support for specific political issues. Inasmuch as proclaimed voter support has political consequences, the voters' world of ideas therefore contributes to the shaping of actual policies.

\subsection{Related literature}

Economic, demographic, and, of late, also political factors are the main sets of macro determinants that economists have traditionally used to explain differences in environmental degradation and differences in the stringency of environmental protection measures. Arguably, the most prominent economic factors relate to an economy's industrial structure, economic development, and openness. Declining industrial employment translates, for example, into lower pollution levels and stricter environmental standards (Neumayer 2003; Gassebner et al. 2008), and income has a non-linear effect on some types of pollution as hypothesized by the Environmental Kuznets Curve (Grossman and Krueger 1995; Lamla 2009). The effect of global economic integration has remained somewhat ambiguous because at least three channels of influence are at work: changes in international trade patterns, the relocation of industries (as conjectured by the Pollution Haven Hypothesis), and the international transfer of technologies. The literature on International Environmental Economics is accordingly vast (Schulze and Ursprung 2001; Damania et al. 2003; Bernauer and Koubi 2009; Cole et al. 2006, Gassebner et al. 2011). The demographic factors, finally, that have been shown to be related to the degradation of the environment include population and household size, urbanization, and age distribution (Cole and Neumayer 2004; Bernauer and Koubi 2009; Jiang and Hardee 2011).

Politics influences the environment first, via the political regime and, second, via the political process. Countries with autocratic regimes have been shown to suffer more from pollution than countries with democratic governments (Congleton 1992; Li and Reuveny 2006), 
and parliamentary democracies more than presidential democracies (Bernauer and Koubi 2009). Barrett and Graddy (2000) find some evidence that political and civil liberties have a positive influence on environmental quality. The prevailing political culture also plays a role. Systemic corruption has a negative effect on the stringency of environmental regulation and so does political instability, at least for low levels of corruption (Fredriksson and Svensson 2003).

When considering the democratic political process, political parties and interest groups come to the fore. Political parties clearly take different environmental policy stances, which, in some cases, even diverge over extended periods (Shipan and Lowry 2001; McCright and Dunlap 2011). Various studies find green and left party power in parliament or government to be associated with lower pollution levels or a larger number of enacted environmental regulations (Neumayer 2003; Bernauer and Koubi 2009; Knill et al. 2010). Gassebner et al. (2011) arrive, however, at the conclusion that among the variables capturing political influences, only the political regime robustly affects the environment.

The political economy approach (Buchanan and Tullock 1975) stimulated models portraying the influence of environmental interest groups (Hillman and Ursprung 1992, 1994; Aidt 1998; Polk and Schmutzler 2005; Fredriksson et al. 2005). The early empirical literature investigated the influence of environmental lobbying on individual pieces of legislation. Studies of the second generation extend the analysis to actual environmental quality (Binder and Neumayer 2005; Fredriksson et al. 2005; Bernauer et al. 2013). The general finding is that environmental lobby groups tend to have a positive effect on environmental quality, the stringency of environmental regulation, and on the ratification of international environmental agreements. Bernauer and Koubi (2009), finally, find that labor union strength contributes to lower environmental quality.

This traditional macro view represents the backdrop of our study that follows a strand of literature that explores the policy attitudes of survey respondents. The economic literature on 
individual attitudes towards international trade policy measures (O’Rourke and Sinnot 2001; Mayda and Rodrik 2005) and towards immigration policies (Scheve and Slaughter 2001; Mayda 2006; O’Rourke and Sinnot 2006) is already quite sizable. In these contexts, also the relationship between voter attitudes and enacted polies has been investigated (Facchini and Mayda 2009). As compared to these strands of the international economics literature, mainly political scientists and sociologists pioneered and advanced the research on environmental concerns and attitudes towards environment protection policies.

The early survey-based sociological literature as summarized by van Liere and Dunlap (1980) emerged in the wake of the environmental movement in the 1970s. This early literature has already identified and scrutinized most factors that standard theories predict to explain public concern with environmental problems. The analyzed factors include gender, age, education, exposure to pollution, urban residence, class, religious beliefs, and, notably, political ideology and attachment to political parties. The subsequent literature has resumed this research agenda but profited from an increased interest by political scientists and economists, larger data sets, and better statistical methods (Kellstedt et al. 2008; Vera-Toscano et al. 2008; Kvaløy et al. 2012; Jorgenson and Givens 2014). Using similar explanatory variables, Konisky et al. (2008) find that environmental concerns translate into environmental policy attitudes. Ziegler (2015) finds that environmental awareness decreases differences in the support for climate policies across people with different political ideologies, and Schwirplies (2015) finds that people who respond to climate change by undertaking adaption measures also undertake protective activities.

An alternative way of identifying the determinants of individual support for environmental protection policies is to use voting results or exit poll data. This method has the advantage of not being subject to the hypothetical bias that plagues survey-based studies. Moreover, biases deriving from expressive behavior (in particular the well-known response 
bias) are certainly less severe in actual vote data, and arguably less severe in exit poll data, than in standard questionnaire surveys. An early exit poll study of voting behavior in a local New Hampshire referendum on an environmental issue is Fischel (1979). Kahn and Matsusaka (1997) examine voting behavior in Californian referenda to estimate the demand for environmental goods. Thalmann (2004) uses exit poll data of a national referendum on three alternative environmental tax proposals in Switzerland and Bornstein and Lanz (2008) analyze the same proposals exploiting the community-level variance in the actual results. ${ }^{3}$

The results of these micro-econometric studies, whether they employ survey data or data relating to actual ballots, indicate that the pattern of the estimates of the typically included covariates is fairly consistent. Especially the estimates of the variables capturing political ideology and party attachment appear to be more in line across studies than the influence of the respective macro-political variables, i.e. government ideology and the party-political composition of parliament.

\subsection{Psychological traits, political ideology, and environmental policy attitudes}

The main objective of incorporating recent insights of behavioral economics into the traditional political economy approach is to show that psychological traits, which represent a constituent part of a person's identity and world of ideas, have a direct influence on the voters' attitudes towards environment protection policies. A direct influence exists if the political indicators traditionally used in political economy, i.e. political ideology and party attachment, do not capture the influence of some dimensions of a person's psychological make-up.

From a technical viewpoint, the incorporated psychological variables play the same role as the socio-economic variables used in traditional empirical models explaining policy attitudes.

\footnotetext{
${ }^{3}$ Halbheer et al. (2006) analyze the approval rate of 45 environmental referenda that took place in Switzerland between 1977 and 2003 to identify the influence of the political-economic environment on voters' support for environmental policy proposals.
} 
Whereas socio-economic variables are necessary to complement the multifaceted concept of political ideologies in studies that attempt to identify the direct influence of economic interest and social imprinting, we introduce our psychological variables to add a new explicitly behavioral dimension to explaining proclaimed policy preferences. In Figure 1 the solid arrows describe the channels of influence investigated in traditional political-economy models, whereas the dashed arrows indicate the influence of the behavioral determinants. Our main hypothesis maintains that psychological or behavioral traits play an important role in shaping political “ideas" in general, and attitudes towards government ordained environmental protection in particular.

We envisage two kinds of psychological traits to be at work. First, we expect an individual's locus of control to influence his or her support for environment protection policies. Behavioral and cognitive psychologists maintain that the locus of control in the sense of Rotter (1966) is an important aspect of personality. The locus of control can be either internal or external. People with an external locus of control believe that exogenous forces determine their lives, whereas people with an internal locus of control attribute success and failure to their own actions. Second, we expect that individuals with an expressive personality are more likely to proclaim support for environment protection policies.

The first conjecture is based on the argument that individuals with an external locus of control cannot conceive of environmental problems being solved without blanket government prescriptions and prohibitions. Individuals with an internal locus of control, on the other hand, are more likely to appreciate that environmental problems can be solved by locally mobilizing individual agents interacting in a self-regulating system governed by suitable general rules. Our results indeed corroborate that the locus of control affects an individual's attitude towards pollution control, and does so via a direct and an indirect channel. The indirect channel runs from an external (internal) locus of control via green (right-wing) partisanship to more (less) 
support for pollution control. This channel of influence corresponds to the arrows (1) and (2) in Figure 1. Moreover, we find strong empirical evidence for a direct channel running from the locus of control immediately to the policy preferences: individuals who are otherwise identical (especially with respect to political ideology), are more in favor of environment protection policies if they have an external rather than an internal locus of control. This finding corresponds to arrow (3) in Figure 1.

The second kind of psychological trait that we introduce in this study relates to expressive behavior. We expect that people with an expressive predisposition are more likely to proclaim support of environment protection policies. After all, proclaimed attitudes and even actual voting behavior are low cost signaling devices because they have no consequences for the voter's actual utility from consumption or wealth (Kirchgässner 1992; Hamlin and Jennings 2011). Without incurring noteworthy costs, political proclamations can therefore be used to maximize expressive utility based on the identity that the individual wishes to confirm. We use two indicators of expressive personalities and find that these indicators are well aligned with the respondents’ proclaimed support for environment protection policies even when controlling for political ideologies. This evidence again indicates the importance of the mechanism described by arrow (3) in Figure 1 and corroborates our hypothesis that support for environment protection policies is to some extent contaminated with expressive rhetoric in the sense of Hillman (2010).

Some previous studies foreshadow our research strategy of incorporating behavioral indicators in a micro-econometric analysis of environmental policy attitudes. In explaining concern for global warming and climate change with the help of a national (US) telephone survey, Kellstedt et al. (2008) include in their set of explanatory variables the variable personal efficacy, which captures the respondents' beliefs in their ability to have an influence on global warming and climate change. Generalizing the concept of personal efficacy or self-efficacy (in 
the sense of Bandura 1997) results in the concept of generalized efficacy that is closely related to the concept of the locus of control (Judge et al. 2002). Using the World Value Survey, Kvaløy et al. (2012) also explore the determinants of the public’s concern for global warming. These authors find support for the generalized efficacy hypothesis: the variables measuring political interest and the belief that one can control one's own fate are positively related to the concern about global warming. Our study differs from Kvaløy et al. (2012) in two respects. First, we focus on political attitudes and not on mere concerns, and consider, second, also expressive behavior as an important psychological trait. Because of our focus on political attitudes, our study relates more closely to Bornstein and Lanz (2008) who incorporate in their vote data analysis indicators of behavioral traits (pro-social behavior), albeit by resorting to information on past voting choices which are, as the authors acknowledge, not really suited to uncover any causal relationship. Even though our approach is, in this respect, not above suspicion either, we believe to have made some headway in showing that it is imperative in studies of political attitudes to account for psychological traits.

We start out by exploring the relationship between respondents’ political attitudes and their proclaimed preferences towards environment protection policies (arrow 2 in Figure 1) and show that the standard left-right cleavage is not as indicative as previous studies on other countries give reason to expect. In Germany, the environmental policy cleavage runs in between the old-established political party lines that include the traditional social-democratic left and the newcomer green ideology that is in Germany represented by a left-wing party. After having established this nexus, we turn to identifying a systematic direct influence of economic interest and social background on proclaimed attitudes towards environment protection policies, i.e. an influence that is not channeled through political ideology (arrow 4 in Figure 1). In a last step, we then show that also personality traits have a direct influence on proclaimed support for environment protection (arrow 3 in Figure 1). We are thus led to 
conclude that political ideologies are an incomplete summary statement of a person's economic interests, social background, and psychological make-up.

We organize the paper as follows. Section 2 presents the dataset and provides some descriptive statistics that shed light on the students' attitudes towards environment protection policies and the relationship between our key explanatory variables (political ideologies and behavioral traits). We also explore the extent to which the behavioral indicators are associated with adherence to the four political ideologies. Section 3 presents the empirical strategy and section 4 the results of our baseline regressions. In section 4 we also explore whether the influence of behavioral stimuli on proclaimed political attitudes differs across ideologies. We then go on to investigate the robustness of our results in section 5. Section 6 concludes.

\section{Data and descriptive analysis}

\subsection{Data}

We use data from a student survey developed by sociologists of education and administered by the Research Group on Higher Education located at the University of Konstanz. The Research group on Higher Education is the only institution that has a long track record in collecting this kind of information in Germany and is, because of that, supported by Germany's Federal Ministry of Education and Research.

Beginning in the winter semester of 1982/83, the Research Group every two or three years collected data on about 8,000 university students (twelve waves). The entire dataset contains 100,420 observations. Students studying at German universities, institutes of technology (technical universities: TU), and universities of applied science are asked to answer questions about their socio-economic background, motivation, expectations, strategies, and satisfaction with student life. The survey also contains questions about life style and political attitudes. The dataset is representative for German students regarding the distribution of basic 
attributes such as gender, field of study, and age. ${ }^{4}$ This dataset has also been used by Fischer et al. (in press).

We use as our benchmark dependent variable support for environmental protection a question asking whether "standing up for solving environmental problems" describes the student's attitude well. The students can choose one of seven answers ranging from strongly disagree (1) to strongly agree (7). This survey question has the advantage of hinting at political modes of action without referring to any specific policy or type of environmental degradation. Moreover, the question was asked in eight out of the twelve waves. In our robustness tests, we replace this benchmark indicator by dependent variables that we gathered from questions that address environmental policy issues head-on by comparing the importance of different policy fields or by addressing specific environmental problems (nuclear energy).

The questions inquiring about the students' political attitudes were first included in the second wave in the academic year 1984/85 and have been asked ever since. The students are always asked in the winter semester. Because most students begin to study in winter, the dataset contains about four times as many students whose record shows an odd number of semesters than students with an even number of semesters. In our baseline model, we focus on the 'regular' students who are in their $1^{\text {st }}, 3^{\text {rd }}, 5^{\text {th }}, 7^{\text {th }}$, or $9^{\text {th }}$ semester. We refer to results derived from the entire sample in the section on robustness tests.

We focus on Christian-conservative, liberal-democratic (i.e. market-oriented), environmentalist, and social-democratic attitudes because these political positions are aligned with the four major parties that have been in the German federal parliament (Bundestag) since 1983: the Christian-conservative CDU/CSU, the liberal-democratic FDP, the social-democratic SPD, and the environmentalist Green party. The survey also allows the students to comment on nationalconservative and communist-Marxist political orientations. Since these political orientations do

\footnotetext{
${ }^{4}$ See Multrus (2004).
} 
however play no role in the contemporary German political discourse, we have chosen not to include them in our study. To be sure, the socialist party "PDS / DIE LINKE" has been represented in the German federal parliament since 1990. The questionnaire does however not contain questions on socialist party preferences. Left-wing policy preferences are thus captured by the social-democratic and environmentalist (green) ideologies, right-wing policy preferences by the Christian-conservative and the liberal-democratic ideologies.

The students are asked to express their views on these four political ideologies on a scale ranging from strongly disagree (1) to strongly agree (7). It is important to note that students express their views on the four political ideologies separately. The exact wording is the following: "Characterizing your overall political attitude: to what extent do you agree with the positions of the following basic political orientations, and to what extent do you disapprove of them?” Students were also asked to express their political views on a left-right scale. We use the left-right variable for robustness tests.

Proclaimed political ideologies and specific policy preferences such as preferences for environmental protection may reflect demographic, socio-cultural, and psychological characteristics. This study focuses on the behavioral determinants of policy proclamations by exploring the influence of two types of personality traits: the locus of control and the inclination to use expressive rhetoric. We have one variable indicating the locus of control. The students were asked whether they agree with the statement that income in our society depends mainly on the individual's performance (categorical scale from 1 to 7; strongly agree: 7). The inclination to use expressive rhetoric is measured with the help of two variables. The students were asked about how much they value the spheres "politics and public life" and "socializing and friends” (categorical scales from 1 to 7; highest importance: 7).

Apart from the demographic variables (gender, age, and studying in East Germany), the survey provides explicit measures of the students’ socio-economic background, religiousness, 
and income aspirations. We use the socio-economic background (categorical scale from 1 to 5; highest: 5) to control for the influence of socially transmitted values and beliefs, importance ascribed to religion (categorical scale from 1 to 7; highest importance: 7) to control for cultural influences, and income aspirations to pick up the student's economic interest which, in political-economic studies, is usually captured by income. Since most students do not have an informative income, we instead use a variable that measures the importance ascribed to earning a high income when choosing a profession (categorical scale from 1 to 7; highest importance: 7).

\subsection{Descriptive analysis}

Our sample contains 26,839 complete observations (i.e. observations that include the entire set of explanatory variables, not including, however, religiousness), 10,826 refer to female students, 16,013 to male students. Our sample does not include students who were older than 23 years when they began to study and students who are younger than 18 years. We only include full-time students.

The average score of support for environmental protection is 5.65 in the overall sample. The score amounts to 5.70 for females and 5.61 for males. German students thus express strong support for environment protection policies. Female students are perhaps a notch more adamant in this respect than their male peers are. Figure 2a depicts the distribution of support for environmental protection for men and women.

The average score of agreement with the Christian-conservative ideology is 3.50 (3.26 for female students and 3.67 for male students). For the liberal-democratic ideology the score of agreement is 4.05 (3.94 for females and 4.12 for males), for the social-democratic ideology 4.63 (4.75 for females and 4.55 for males), and for the green ideology 4.45 (4.73 for females and 4.26 for males). The German student body thus has a leaning towards social-democratic 
and green policy positions, and female students are even more in agreement with the political left (which, in our sample, includes the social democrats and the greens) than their male peers. This gender gap in political preferences is well documented in the literature (Lott and Kenny 1999; Box-Steffensmeier et al. 2004; and, for Germany, Inglehart and Norris 2000). Figure 2b introduces the concept of partisan students, i.e. students who assigned values of 6 or 7 to exactly one political ideology and values of 5 or lower to all other ideologies. Partisans are thus students who can unambiguously be associated with one of the four political ideologies. Figure 2b depicts how the political attitudes of partisans relate to the support for environment protection. Students who agree with the ideologies of the Christian-conservative and the liberal-democratic ideology proclaim less support for environment protection than students who agree with the social-democratic and, above all, the green ideology.

Figure 3 depicts the relationship between the students’ psychological traits and their proclaimed environmental attitudes, ranging, according to Figure 2a, for most students between 5 and 7. We also include in this Figure the association with religiousness because religiosity and having an external locus of control appear to capture related mindsets. It transpires that non-religious students and students with an internal locus of control are less in favor of environment protection policies than religious students and students with an external locus of control. The inclination to use expressive rhetoric as measured by the "importance of politics and public life" and the "importance of socializing and friends" also clearly relates to the students' attitudes towards environment protection policies. Students with these “expressiveness” traits support environment protection policies more than students who do not have this inclination.

In order to obtain a feeling for whether the results reported in Figure 3 can be attributed to people with certain personalities selecting themselves into followers or partisans of different political ideologies which then influence their policy stances on specific issues, we depict in 
Figure 4 the distributions of the personality traits (including religiousness) for partisans only. The personality trait distributions depicted in the last two panels do not greatly differ across political ideologies. The distributions of importance of politics and public life are almost indistinguishable. Left-wing partisans (i.e. social democrats and greens) are however somewhat more likely to report that socializing and friends are very important in their lives. Panel 4a documents the unsurprising fact that supporters of the Christian-conservative ideology are, on average, more religious than the supporters of the secular ideologies. More interesting is the message provided in panel 4b: the four types of partisans differ substantially with respect to the personality trait locus of control. Left-wing partisans are guided by a more external locus of control, whereas right-wing partisans are guided by a more internal locus of control. In plain English: left-wingers believe that external forces mainly determine people's fortune, i.e. forces they cannot control, whereas right-wingers believe that people are primarily responsible for their own fate. This result indicates that political ideologies or attitudes depend to some extent on psychological traits, thereby contradicting the traditional political-economic (and also the classical Marxist) view that political stances reflect only the individual's economic interests. ${ }^{5}$

\section{The empirical model}

Because the variable measuring support of environmental protection is categorical (values from 1 to 7$)$, we specify an ordered probit model of the form:

$$
\begin{aligned}
& \text { Support for Environmental Protection }_{i}=\Sigma_{j} \alpha_{j} \text { Political Attitude }_{i j}+\Sigma_{k} \beta_{k} \text { Personality }_{i k} \\
& +\delta V_{i}+\varepsilon Y_{i}+\zeta X_{i}+\eta Z_{i}+u_{i} \\
& \text { with } i=1, \ldots, 26839 ; j=1, \ldots, 4 ; k=1, \ldots, 3
\end{aligned}
$$

\footnotetext{
${ }^{5}$ Table A1 in the Appendix reports in some more detail how the political preferences and personality traits are related to the support of environmental protection.
} 
where Support for Environmental Protection $_{i}$ is individual i's stated support. Political Attitude $e_{i j}$ is the political attitude of individual $i$ towards party $j$. It is important to recall that the students express their views on the four political ideologies separately, implying that a student could, in principle, completely agree with the social-democratic and Christian-conservative ideology. Therefore, there is no reference category. Personality $i k$ contains one variable capturing the respondent's locus of control and two variables capturing the respondents' susceptibility to making use of expressive rhetoric ("importance of politics and public life" and "importance of socializing and friends”). We follow here a parsimonious strategy and include the indicated values of these categorical variables, i.e. we do not record the chosen answers as dummy variables. We are aware that this assumes a linear relationship across categories. Inferences do however not change when we include dummy variables for each category; an exception is the locus of control variable (see section 4.1).

$V_{i}$ is a vector of demographic control variables including the female dummy variable, the age of individual $i$, and an East Germany dummy variable. The vector $Y_{i}$ captures the respondents' socio-cultural characteristics (i.e. importance of high income, socio-economic background, and in some regressions religiousness). The socio-cultural variables are categorical. For parsimony reasons we do not include dummy variables for each category of the socio-economic variables in the baseline model. Inferences regarding the effect of the socio-economic variables do however not change when we include dummy variables for each category of answers. $X_{i}$ is a vector of dummy variables for the survey waves (reference category: wave nine) and $Z_{i}$ is a vector of fixed university effects.

We include the various blocks of control variables consecutively because not all control variables are available for all observations. Table 1 reports the descriptive statistics of all variables. 


\section{Results}

\subsection{Baseline regressions: All students}

Table 2 presents the coefficient estimates of our baseline ordered probit model (we discuss the numerical meaning of the estimated effects by describing marginal effects at the end of this section). The first column shows the results when we include only the political attitudes, the wave dummies, and the university fixed effects. The coefficients of the political attitudes variables are statistically significant at the $1 \%$ level. Increasing support for the Christianconservative, market-oriented, and social-democratic ideologies is associated with decreasing support for environment protection policies, whereas support for the green ideology varies positively with support for environment protection policies. The environmental policy cleavage, at least among young, highly educated Germans, thus does not run along the left-right divide.

The coefficient estimates of the wave dummy variables show that beginning from the early 1990s (wave 5) support for environmental protection has decreased across the board. This decline may reflect waning confidence in international coordination of pollution control. In the 1980s, the public still perceived pollution control as manageable. Water pollution, acid rain, the dying forest syndrome, and nuclear power plants sprang to mind when people discussed environmental protection - and these were all problems that could be tackled by local and national regulation. When, in the 1990s, the global dimension of environmental plight (in particular global warming) began to replace the local aspects in the political discourse, the focus shifted to international environmental agreements and the attendant free rider and compensation problems that turned out to be practically insurmountable. It is perhaps not surprising that the public reacted to this quagmire by increasingly turning its back to the national government's unrewarding solo efforts.

In column (2) we add the three demographic variables: a female dummy variable, the respondent's age, and a dummy variable indicating whether the respondent studies at a 
university in East Germany. The estimated coefficient of the female dummy variable shows that even when controlling for political ideology, women are more in favor of environmental protection than men are. The identified gender effect is not only perfectly in line with our descriptive analysis, it also corroborates that political attitudes provide a rather incomplete picture of proclaimed policy preferences. The estimated coefficient of the age variable reproduces the standard result that concern for the environment increases with age, and the estimated coefficient of the East Germany dummy variable indicates that among highly educated young Germans the socialist past with the attendant inherited waste has left no traces.

The set of our socio-cultural variables includes income aspirations, socio-economic background, and religiousness. Since however only relatively few students answered the question regarding religion and faith, we include at this stage only the first two variables. The economic calculus boils down to comparing tax costs and benefits of environment protection policies. Since the German tax system is rather progressive, the tax-cost effect predicts that students who aspire to high incomes are less in favor of environment protection than students who expect to do less well in terms of earning power. The benefits of environment protection may however offset the negative tax-cost effect if environmental quality is a normal good. The estimated sign of the variable that captures the student's expected income shows that the taxcost effect dominates the benefit effect: students aspiring to high incomes are less inclined to proclaim support for environment protection policies. This result is consistent with the findings of previous studies (Fischel 1979; Thalmann 2004; Jorgenson and Givens 2014). Since our survey evidence relates to university students who will, in general, earn above average incomes, it is however conceivable that this result does not carry over to the entire income distribution. Indeed, several studies found a hump-shaped relationship between income and support for environmental protection (Kahn and Matsusaka 1997; Bornstein and Lanz 2008). It is thus possible that the negative relationship identified by us simply reflects the fact that we are dealing with a sample of prospective above-average income earners. In short, our estimate is 
also consistent with an inverted hump-shaped relationship of which we have captured with our special sample only the downward-sloping part.

The last variable added in column (2) describes the respondents' socio-economic background. The socio-economic background is a convenient catchall indicator of classspecific value judgments and is often used to capture a potential social imprinting effect. We find that support for environment protection policies does not depend on the respondent's socio-economic background. We speculate that whatever influence the socio-economic background may have on the students' attitudes, this influence is picked up by their political ideology. ${ }^{6}$

In column (3) we introduce the behavioral variables. We find that students with an internal locus of control are less in favor of environmental protection than students with an external locus of control. Adding a squared term of the locus of control (results not shown) indicates however that the negative effect is driven by respondents with an external or neutral locus of control, i.e. respondents with an internal locus of control rating ranging from 1 to $4 .^{7}$ Respondents with an internal locus of control (ratings 5 and 6) are not less conservationminded than respondents with a neutral locus of control, and respondents with a very distinct internal locus of control (rating 7), accounting for about $10 \%$ of our sample, may even be a little more ecology-minded than respondents with a neutral rating. The estimated coefficients of the two variables indicating an affinity for expressive behavior also have the expected positive sign and are statistically highly significant: students who declare that "politics and public life" and "socializing and friends" are important ingredients of their social lives

\footnotetext{
${ }^{6}$ Jorgenson and Givens (2014), for example, find a statistically significant effect of social class on environmental concerns, but this multilevel analysis of individuals in 37 countries cannot control for political ideologies.

${ }^{7}$ Technically speaking, the estimate of the squared term is positive and statistically significant, indicating a Ushaped relationship. Using the squared term of the locus of control may not be suitable because the scale matters for this categorical variable. Following Aidt (2009) by including dummy variables for low (1-2), intermediate (35 ), and high ratings (6-7) of the locus of control corroborates the U-shaped relationship, with the right part of the "U" being smaller than the left part.
} 
proclaim to be more in favor of environmental protection. These two variables are also statistically significant at the $1 \%$ level when we include them separately (results not shown).

In column (4) we show the estimates of our preferred specification that includes all explanatory variables. The result reinforces the impression that emerges from comparing the estimates across specifications (1)-(3): the estimated effects are very stable and thus indicate a robust relationship. This robustness applies in particular to our focal behavioral determinants, indicating that an individual's locus of control and expressiveness have a statistically significant influence on his or her proclaimed support for environment protection policies.

When including the religiousness variable in our preferred specification (4), the estimates of the important explanatory variables do not change substantially (see column 5). The ideology variables as well as the psychological trait variables remain statistically significant at the highest level. The estimate of the religiousness variable has the expected positive sign and is statistically significant at the $1 \%$ level. Including religiousness renders the gender and age variables to lack statistical significance. This is however a consequence of the dramatically reduced sample size.

We computed the marginal effects for our preferred specification (column 4) when support for environment protection assumes the value 6 ("agree with being characterized as a supporter of environmental protection”). The results are shown in column (6) of Table 2. All marginal effects are statistically significant at the $1 \%$ or $5 \%$ level, except the East Germany dummy and the socio-economic background. The interpretation of the marginal effects of the crucial variables is the following. When agreement with the Christian-conservative (marketoriented) ideology increases by one point (on the scale from 1 to 7 ), the probability to agree with environment protection (i.e. to tick category 6 when asked about environmental protection) decreases by $0.20(0.12)$ percentage points. On the left of the political spectrum, the probability to agree with environment protection also decreases (by 0.12 percentage points) 
when the alignment with the social-democratic ideology increases by one point, but increases by 1.32 percentage points when the alignment with the green ideology increases by one point. An increase in the importance of politics and public life (socializing and friends) by one point increases the probability to agree with environment protection by $0.39(0.54)$ percentage points and an increase in the internal locus of control by one point decreases the probability to agree with environmental protection by 0.08 percentage points. ${ }^{8}$

\subsection{Partisan students}

So far, we have included all regular students as defined in section 2.1. Since many of these students align themselves with more than one political ideology, we now test whether inferences change when we consider only partisan students, i.e. students who express strong preferences for exactly one ideology. We thus restricted the sample to those students who assign values of 6 or 7 to exactly one political ideology and values of 5 or lower to all other ideologies. Interestingly, this leaves us with only about $47 \%$ of the respondents, suggesting that the share of swing voters is likely to exceed $50 \%$, at least among young academics. ${ }^{9}$ Table 3 shows that partisan students are not much different from students who are ideologically less committed. Noticeable is that gender and age do not appear to influence the partisans. Moreover, social-democratic partisans are much less inclined to support environment protection policies than rank-and-file social democrats, perhaps because social-democratic partisans feel the need to accommodate in their rhetoric the social-democratic party's traditional working-class constituency and trade union members, both of which are rather hesitant to jeopardize blue-collar jobs by supporting fancy pollution control policies (Bernauer

\footnotetext{
${ }^{8}$ The marginal effect of the locus of control variable is small because of the L-shaped or slightly U-shaped relationship between the internal locus of control and support for environment protection policies.

${ }^{9}$ In the German voter population at large, the fraction of swing voters is about $40 \%$.
} 
and Koubi 2009). Such considerations do however not restrict the average university students with an affinity to the social-democratic ideology.

Focusing on partisan students, we can also address the question as to whether the effect of personality traits on the support for environmental protection varies across the four types of partisans. We therefore estimated our empirical model using subsamples defined by the four types of partisans. In Table 4, we report the coefficient estimates of the regressions including all explanatory variables (except religiousness and, of course, the political attitudes). ${ }^{10}$ The estimates show that an external locus of control and an inclination to indulge in expressive rhetoric both increase proclaimed support for environment protection policies for all four types of partisans. The locus of control is not statistically significant for social-democratic partisans, but we will show in the robustness test section that this result is nevertheless quite robust. In short: our results imply that the behavior of all types of partisans is subject to psychological influences.

The positive female effect that we identified for the entire student body disappears in our preferred specification when we restrict the sample to partisan students (see Table 3). The estimates in Table 4 now hint at why the gender effect is so fragile: a gender cleavage exists only among market-oriented and social-democratic partisans. Also interesting are the estimates of the effect of the socio-economic background. It transpires that the zero effect documented in Tables 2 and 3 does not apply to right-wing partisans. Christian-conservative and liberaldemocratic partisans with an upper-class background appear to be significantly less keen on environment protection policies than middle and lower-class advocates of these political ideologies.

Finally, it is worth mentioning that economic motives, captured by the "importance of high income" variable, play a role for all types of partisans; the estimated coefficient is

\footnotetext{
${ }^{10}$ The wave dummies are also included but we do not show the estimated coefficients.
} 
negative and statistically significant in all four regressions. This indicates that even ideologically committed partisans react to economic incentives.

\section{Robustness tests}

We tested the robustness of our results in two ways. First, we replaced the dependent variable “support for environmental protection” with indicators that explicitly address specific policy aspects of environmental protection. Second, we estimated the preferred specification of the baseline model (Table 2, column 4) by using different samples and independent variables.

\subsection{Different dependent variables}

When eliciting attitudes towards environmental control without referring to any specific policy measures or consequences, it is perhaps predictable that the respondents proclaim strong support by feel or instinct, i.e. without thinking much about the issue. We therefore check whether explicitly referring to potential costs of environmental policy measures diminishes the influence of psychological traits on the elicited response. We do so by substituting our baseline dependent variable with the response to a question that addresses the trade-off between environmental quality and economic prosperity. Moreover, we also checked whether the influence of the analyzed psychological traits remains unaltered when the respondents have to evaluate specific policies. The exact wording of the question that we used to arrive at alternative dependent variables is the following: "How do you feel about the following political objectives: which do you support and which do you object to? (1) Priority of environment protection over economic growth (question 756); ${ }^{11}$ (2) Increased utilization of nuclear energy and construction of new nuclear plants (question 762); (3) Abandoning nuclear energy and shutdown of nuclear power plants (question 764).” The priority question was asked in all

\footnotetext{
${ }^{11}$ The formulation of this question is of course akin to the questions asked in the literature on the willingness to pay for public environment protection programs (see, for example, Lee and Cameron 2008, Cai et al. 2010).
} 
waves (except 2000/01), the increased utilization question in four waves from 1982/831989/90, and the shutdown question in seven waves from 1992/93-1997/98 and 2003/042012/13.

In Table 5 we report the coefficient estimates when using the alternative dependent variables in our preferred specification of the regression equation. The results thus correspond to Table 2, column (4) and Table 3, column (4). Even though all independent variables are included, we only report the estimates of the behavioral variables. Table 5 moreover reports the signs of the estimates of the regressions reported in Table 4 when using the alternative dependent variables. The results confirm that respondents with an internal locus of control are less inclined to pay lip service to ecological correctness. Notice, that "political priority of environment protection over economic growth" and "abandoning nuclear energy and shutdown of nuclear power plants" have environment-friendly connotations, whereas "increased utilization of nuclear energy and construction of new nuclear plants” is generally regarded to harm the environment. An internal locus of control is thus expected to have a negative effect on the first two policies and a positive effect on the third policy. This is exactly what we find for all students, for partisan students, and even for all four types of partisan students.

The same clean picture emerges for our indicator of expressive behavior that uses the respondents' self-reported appreciation of "socializing and friends". The other indicator of expressive behavior (“importance of politics and public life”) also confirms our baseline results when using the alternative dependent variable "abandoning nuclear power production”. This is not surprising since being opposed to nuclear power attained almost the status of a confession of faith after German reunification (1990) when this question was asked. In the 1980s, nuclear power production was however still a controversial issue. Our results nevertheless show that even then students who highly appreciated "politics and public life" were more likely to proclaim anti-nuclear attitudes. This also applies to the subsample of partisan students. Only 
when discriminating between partisans of different ideologies, small differences emerge. It transpires that in the 1980s Christian-conservative partisans with a high appreciation of "politics and public life” did not proclaim to be against increased use of nuclear power; the estimated coefficient is however small and barely statistically significant.

Turning now to the relationship between highly appreciating "politics and public life" and proclaiming to prioritize environmental quality over economic growth, the results reported in Table 5 indicate that among the general student body and also among partisan students no effect is discernable. Differences emerge however again, when focusing on partisans of different ideologies. Left-wing partisans (social democrats and greens) who are attracted by politics and public life are more inclined to proclaim environmental attitudes that are appreciated in leftist circles; right-wing partisans (Christian-conservatives and free democrats), on the other hand, cut a better figure in their circles by advocating economic efficiency and prosperity. Interestingly and significantly, these differences in expressive behavior disappear, when, instead of a political and public life audience, our second indicator of expressiveness prompts a general audience of sociable people and friends.

Overall, our regressions with alternative dependent variables thus very nicely confirm our baseline results.

\subsection{Different samples and explanatory variables}

We estimated the preferred specifications of our empirical model (columns 4 in Tables 2 and 3) for males and females separately. With one notable exception, replicating Tables 2 and 3 does not change the inferences. The exception concerns the effect of market-oriented political attitudes: female students' support for environment protection policies does not decrease as they become more attached to the liberal-democratic creed: the respective coefficient does not turn out to be statistically significant. Male students and partisans thus drive the negative 
association of environmental protection and market-oriented attitudes identified in Tables 2 and 3.

So far, we focused on students whose record shows an odd number of semesters, arguing that the group of students whose record shows an even number of semesters is heterogeneous and differs from the much larger group of "regular" students. As a robustness test, we included also students whose record shows an even number of semesters and students who studied for more than nine semesters. When replicating Tables 2-4, inferences do not change.

Our standard definition labels students as partisans if they assigned the value 6 or 7 to exactly one political ideology and the value 5 or lower to all other ideologies. We tested whether inferences change, when defining as partisans those students who assigned the value 5, 6 or 7 to exactly one political ideology and the value 4 or lower to all other ideologies. Inferences regarding the results reported in Table 3 do not change.

We merged the seven categories of the dependent variable ranging from strongly disagree (1) to strongly agree (7) into three categories. We grouped the two categories strongly disagree (1) and disagree (2), the three intermediate categories, and the two categories agree (6) and strongly agree (7). Replicating Tables 2-4, inferences do not change. The results become even stronger: The internal locus of control now also exerts for social-democratic partisans the expected negative influence on their environmental attitudes (statistically significant at the $5 \%$ level).

We replaced the four political ideology variables by a variable that measures the students' political ideology on a left-right scale. Replicating Tables 2 and 3, inferences do not change: The coefficient estimates are always statistically significant at the $1 \%$ level and show that right-wing students favor less environment protection than left-wing students. In particular, inferences regarding the personality trait variables do not change. 
To isolate the effects of political ideologies and personality traits from a further potentially confounding factor working through specialized knowledge, we also included dummy variables indicating the students' field of study (humanities, social sciences, economics and business, law, medicine, engineering, natural sciences, and other subjects). Replicating Tables 2-4, the results show in most specifications that natural science and engineering students support environmental protection more strongly than medical students (reference category), and humanities, social science, law, and economics and business students less so. When including these academic field variables, inferences regarding the political attitudes and personality trait variables do not change.

\section{Conclusion}

The objective of this study has been to show that proclaimed support for environment protection policies depends, among other factors, on psychological traits, in particular on the proclaiming person's locus of control and on psychological traits that capture his or her susceptibility to making use of expressive rhetoric.

Deeply rooted mental routines greatly influence everyday low-cost choices. Since spontaneously elicited policy pronouncements come at low cost, it is certainly not far-fetched to hypothesize that these pronouncements are influenced by psychological traits, especially by the locus of control that has been shown to represent a highly fundamental trait of the self. Spontaneous policy pronouncements, moreover, provide opportunities for expressive benefits through low-cost identity confirmation. Since proclamations of general political ideologies are also liable to be used to signal an assumed identity as proclamations of specific policy preferences, we first established a firm relationship between proclaimed political ideologies and attitudes towards environment protection policies. Our study’s first result confirms a very robust correspondence pattern of political ideologies and attitudes towards environment 
protection policies. Interestingly, we do however not find the cleavage that similar studies have usually identified, i.e. a cleavage between the political right and left. As compared to the political landscapes in other countries, we rather find the environmental policy stance of the German social democrats to be closer to the environmental policy views of the German rightwing parties, and the liberal democrats to be closer to the political center. The environmental policy stance of the German liberal democrats is thus much more ecologically compatible than the policy views of market-oriented parties in other countries, indicating that libertarian views that are not captured by vested interests can blend perfectly well with efficient environmental policies.

To test whether proclaimed support for environment protection policies depends on psychological traits when controlling for political ideology, we introduce the locus of control as an indicator of a person's deeply rooted belief system and personality traits that are indicative of expressiveness. We hypothesize that people with an external locus of control are especially supportive of environment protection policies and likewise people with an expressive personality, i.e. people whose self-esteem depends a great deal on the impression they make on their social environment. We find that this hypothesis stands up well to the empirical evidence. Our regression results show that, apart from the traditional determinants of policy views, the locus of control and psychological traits indicative of expressive behavior play a substantial role in shaping a person's policy pronouncements. We also show that partisans of all political ideologies use expressive rhetoric, at least when advocating environment protection policies.

This insight has potentially far reaching consequences. The fundamental problem of expressive rhetoric is that deceptive misrepresentation and psychic repression of true preferences may well result in policy outcomes that a large part of the electorate disapproves of. Such dysfunctions of the political system are not necessarily self-correcting. The well-known 
voting externalities, which accrue because voters do not internalize the consequences of their behavior for others (Tullock 1959), may therefore, in the presence of expressive rhetoric or voting, become substantially more severe.

We readily admit that the evidence mustered in our study is rather suggestive than conclusive. This is so because of dependence on data from a questionnaire survey that was designed to investigate study related issues and not the question that we are interested in. We were however fortunate to be able to gather from this survey reasonably suitable evidence for our purposes. A more powerful research strategy targeted at measuring the behavioral content of policy pronouncements would however require a set of questions that squarely aims at the core of the research question. Despite this caveat, we believe that our results convincingly show that all policy pronouncements are likely to be fraught with behavioral biases akin to, but much more encompassing and momentous, than the well-known response bias.

Providing evidence for behavioral determinants of proclaimed policy preferences does of course not imply that all policy pronouncements of the general public are solely based on instinct or motivated by the attendant expressive benefits. Our study rather shows that, apart from psychological modes of behavior, proclaimed support for environmental protection also depends on various factors that socio-economic studies traditionally employ to explain policy preferences. These factors include in particular expected individual economic costs and benefits. 


\section{References}

Aidt TS (1998). Political internalization of economic externalities and environmental policy, Journal of Public Economics 69, 1-16.

Aidt TS (2009). Corruption, institutions, and economic development, Oxford Review of Economic Policy 25, 271-291.

Bandura A (1977). Self-efficacy: Toward a unifying theory of behavioral change, Psychological Review 84(2), 191-215.

Barrett S, Graddy K (2000). Freedom, growth and the environment, Environment and Development Economics 5, 433-456.

Bernauer T, Böhmelt T, Koubi V (2013). Is there a democracy-civil society paradox in global environmental governance? Global Environmental Politics 13(1), 88-107.

Bernauer T, Koubi V (2009). Effects of political institutions on air quality, Ecological Economics 68, 1355-1365.

Binder S, Neumayer E (2005). Environmental pressure group strength and air pollution: An empirical analysis. Ecological Economics 55, 527-538.

Bornstein N, Lanz B (2008). Voting on the environment: Price or ideology? Evidence from Swiss referendums, Ecological Economics 67, 430-440.

Box-Steffensmeier JM, De Boef S, Lin T-M (2004). The dynamics of the partisan gender gap, American Political Science Review 98(3), 515-528.

Buchanan JM, G Tullock (1975). Polluters’ profits and political response: Direct controls versus taxes, American Economic Review 65(1), 139-147.

Cai B, Cameron TA, Gerdes GR (2010). Distributional preferences and the incidence of costs and benefits in climate change policy, Environmental and Resource Economics 46, 429458.

Cole MA, Elliott RJR, Fredriksson PG (2006). Endogenous pollution havens: Does FDI influence environmental regulations? Scandinavian Journal of Economics 108(1), 157178.

Cole MA, Neumayer E (2004). Examining the impact of demographic factors on air pollution, Population and Environment 26, 5-21.

Congleton RD (1992). Political institutions and pollution control, Review of Economics and Statistics, 74(3), 412-421.

Damania R, Fredriksson PG, List JA (2003). Trade liberalization, corruption, and environmental policy formation: Theory and evidence, Journal of Environmental Economics and Management 46, 490-512.

Facchini G, Mayda AM (2009). The political economy of immigration policy, Human Development Research Paper 3, UNDP. 
Fischel WA (1979). Determinants of voting on environmental quality: A study of a New Hampshire pulp mill referendum, Journal of Environmental Economics and Management 6, 107-118.

Fischer M, Kauder B, Potrafke N, Ursprung HW (in press). Support for free-market policies and reforms: Does the field of study influence students' political attitudes? European Journal of Political Economy.

Fredriksson PG, Svensson J (2003). Political instability, corruption and policy formation: The case of environmental policy, Journal of Public Economics 87, 1383-1405.

Fredriksson PG, Neumayer E, Damania R, Gates S (2005). Environmentalism, democracy, and pollution control, Journal of Environmental Economics and Management 49, 343-365.

Galais C, Blais A (2016). Beyond rationalization: Voting out of duty or expressing duty after voting? International Political Science Review 37(2), 213-229.

Gassebner M, Gaston N, Lamla MJ (2008). Relief for the environment? The importance of an increasingly unimportant industrial sector, Economic Inquiry 46(2), 160-178.

Gassebner M, Lamla MJ, Sturm J-E (2011). Determinants of pollution: What do we really know? Oxford Economic Papers 63, 568-595.

Gerber AS, Huber GA, Doherty D, Dowling CM (2011). The Big Five personality traits in the political arena, Annual Review of Political Science 14, 265-287.

Gerber AS, Huber GA, Doherty D, Dowling CM, Ha SE (2010). Personality and political attitudes: Relationships across issue domains and political contexts, American Political Science Review 104(1), 111-133.

Grossman GM, Krueger AB (1995). Economic growth and the environment, Quarterly Journal of Economics 110(2), 353-377.

Halbheer D, Niggli S, Schmutzler A (2006). What does it take to sell environmental policy? An empirical analysis of referendum data, Environmental \& Resource Economics 33, 441-462.

Hamlin A, Jennings C (2011). Expressive political behaviour: Foundations, scope and implications, British Journal of Political Science 41, 645-670.

Hillman AL (2010). Expressive behavior in economics and politics, European Journal of Political Economy 26, 403-418.

Hillman AL, Ursprung HW (1992). The influence of environmental concerns on the political determination of trade policy. In: Anderson K and Blackhurst R (Eds.), The Greening of World Trade Issues, Harvester Wheatsheaf, New York, pp. 195-220.

Hillman AL, Ursprung HW (1994). Greens, super greens, and international trade policy: Environmental concerns and protectionism. In: Carraro C (Ed.), Trade, Innovation, Environment, Springer, Heidelberg, pp. 75-108. 
Inglehart R, Norris P (2000). The developmental theory of the gender gap: Women's and men's voting behavior in global perspective, International Political Science Review 21(4), 441-463.

Jiang L, Hardee K (2011). How do recent population trends matter to climate change? Population Research and Policy Review 30, 287-312.

Jorgenson AK, Givens JE (2014). Economic globalization and environmental concern: A multilevel analysis of individuals within 37 nations, Environment and Behavior 46(7), 848-871.

Judge TA, Erez A, Bono JE, Thoresen CJ (2002). Are measures of self-esteem, neuroticism, locus of control, and generalized self-efficacy indicators of a common core construct? Journal of Personality and Social Psychology 83(3), 693-710.

Kahn ME, Matsusaka JG (1997). Demand for environmental goods: Evidence from voting patterns on California initiatives, Journal of Law and Economics 40, 137-173.

Kellstedt PM, Zahran S, Vedlitz A (2008). Personal efficacy, the information environment, and attitudes toward global warming and climate change in the United States, Risk Analysis 28(1), 113-126.

Kirchgässner G (1992). Towards a theory of low-cost decisions, European Journal of Political Economy 8, 305-320.

Knill C, Debus M, Heichel S (2010). Do parties matter in internationalised policy areas? The impact of political parties on environmental policy outputs in 18 OECD countries, 19702000, European Journal of Political Research 49, 301-336.

Konisky DM, Milyo J, Richardson Jr. LE (2008). Environmental policy attitudes: Issues, geographical scale, and political trust, Social Science Quarterly 89(5), 1066-1085.

Kvaløy B, Finseraas H, Listhaug O (2012). The publics’ concern for global warming: A crossnational study of 47 countries, Journal of Peace Research 49(1), 11-22.

Lamla MJ (2009). Long-run determinants of pollution: A robustness analysis, Ecological Economics 69, 135-144.

Lee JJ, Cameron TA (2008). Popular support for climate change mitigation: Evidence from a general population mail survey, Environmental and Resource Economics 41, 223-248.

Li Q, Reuveny R (2006). Democracy and environmental degradation, International Studies Quarterly 50, 935-956.

Lott JR, Kenny LW (1999). Did women's suffrage change the size and scope of government? Journal of Political Economy 107(6), 1163-1198.

Mayda AM (2006). Who is against immigration? A cross-country investigation of individual attitudes toward immigrants, Review of Economics and Statistics 88(3), 510-530.

Mayda AM, Rodrik D (2005). Why are some people (and countries) more protectionist than others? European Economic Review 49, 1393-1430. 
McCright AM, Dunlap RE (2011). The politicization of climate change and polarization in the American public's views of global warming, 2001-2010, The Sociological Quarterly 52, 155-194.

Multrus F (2004). Fachkulturen: Begriffsbestimmung, Herleitung und Analysen, Dissertation, University of Konstanz.

Neumayer E (2003). Are left-wing party strength and corporatism good for the environment? Evidence from panel analysis of air pollution in OECD countries, Ecological Economics 45, 203-220.

O’Rourke KH, Sinnott R (2001). The determinants of individual trade policy preferences: International survey evidence. In: Collins SM, Rodrik D (Eds.), Brookings Trade Forum: 2001, Brookings Institute Press, Washington DC, pp. 157-206.

O’Rourke KH, Sinnott R (2006). The determinants of individual attitudes towards immigration, European Journal of Political Economy 22, 838-861.

Polk A, Schmutzler A (2005). Lobbying against environmental regulation vs. lobbying for loopholes, European Journal of Political Economy 21, 915-931.

Rotter JB (1966). Generalized expectancies for internal versus external control of reinforcement, Psychological Monographs: General and Applied 80(1), 1-28.

Scheve KF, Slaughter MJ (2001). Labor market competition and individual preferences over immigration policy, Review of Economics and Statistics 83(1), 133-145.

Schulze GG, Ursprung HW (2001). International Environmental Economics: A Survey of the Issues, Oxford University Press, Oxford.

Schwirplies C (2015). Adaptation vs. climate protection: Responses to climate change and policy preferences of individuals in China, Germany, and the USA, unpublished paper.

Shipan CR, Lowry WR (2001). Environmental policy and party divergence in Congress. Political Research Quarterly 54(2), 245-263.

Thalmann P (2004). The public acceptance of green taxes: 2 million voters express their opinion, Public Choice 119, 179-217.

Tullock G (1959). Problems of majority voting, Journal of Political Economy 67(6), 571-579.

van Liere KD, Dunlap RE (1980). The social bases of environmental concern: A review of hypotheses, explanations and empirical evidence, Public Opinion Quarterly 44(2), 181197.

Vera-Toscano E, Gómez-Limón JA, Moyano E, Garrido F (2008). Factors determining citizen's attitudes towards agri-environmental property rights, Environmental and Resource Economics 41, 541-561.

Ziegler A (2015). On the relevance of ideology and environmental values for climate change beliefs, climate policy support, and climate protection activities: An empirical crosscountry analysis, unpublished paper. 
Table 1: Descriptive statistics.

\begin{tabular}{|c|c|c|c|c|c|c|}
\hline & Name in dataset & Obs. & Mean & Std. Dev. & Min & Max \\
\hline Support for environmental protection & v529 & 26839 & 5.65 & 1.25 & 1 & 7 \\
\hline Priority of environment over econ. growth & v756 & 35900 & 5.73 & 1.36 & 1 & 7 \\
\hline Increased utilization of nuclear energy & v762 & 12985 & 2.57 & 1.75 & 1 & 7 \\
\hline Abandoning nuclear energy & v764 & 22918 & 4.61 & 1.98 & 1 & 7 \\
\hline Christian-conservative & v716 & 26839 & 3.50 & 1.81 & 1 & 7 \\
\hline Market-oriented & v719 & 26839 & 4.05 & 1.53 & 1 & 7 \\
\hline Social-democratic & v721 & 26839 & 4.63 & 1.38 & 1 & 7 \\
\hline Green & v717 & 26839 & 4.45 & 1.62 & 1 & 7 \\
\hline Female & v3 & 26839 & 0.40 & 0.49 & 0 & 1 \\
\hline Age & v18 & 26839 & 22.65 & 2.00 & 18 & 28 \\
\hline East Germany & v5 & 26839 & 0.16 & 0.37 & 0 & 1 \\
\hline Importance of high income & v677 & 26839 & 4.63 & 1.48 & 1 & 7 \\
\hline Socio-economic background & v932 & 26839 & 2.92 & 1.23 & 1 & 5 \\
\hline Importance of religion and faith & v543 & 17643 & 2.99 & 1.98 & 1 & 7 \\
\hline Internal locus of control & v799 & 26839 & 4.24 & 1.71 & 1 & 7 \\
\hline Importance of politics and public life & v534 & 26839 & 4.62 & 1.47 & 1 & 7 \\
\hline Importance of socializing and friends & v542 & 26839 & 6.07 & 1.01 & 1 & 7 \\
\hline Good labor market prospects & v655 \& v656 & 9884 & 0.34 & 0.47 & 0 & 1 \\
\hline Political position: extreme left (right) $=1(7)$ & v714 & 24120 & 3.32 & 1.31 & 1 & 7 \\
\hline Humanities & v8 (category 1 ) & 26735 & 0.14 & 0.35 & 0 & 1 \\
\hline Social sciences & v8 (categories 2 \& 9) & 26735 & 0.08 & 0.27 & 0 & 1 \\
\hline Economics & v8 (categories 4 \& 10) & 26735 & 0.15 & 0.36 & 0 & 1 \\
\hline Law & v8 (category 3) & 26735 & 0.08 & 0.28 & 0 & 1 \\
\hline Medicine & v8 (category 5) & 26735 & 0.08 & 0.27 & 0 & 1 \\
\hline Engineering & v8 (categories 7 \& 11) & 26735 & 0.24 & 0.43 & 0 & 1 \\
\hline Natural sciences & v8 (category 6) & 26735 & 0.18 & 0.38 & 0 & 1 \\
\hline Other subjects & v8 (categories 8 \& 12) & 26735 & 0.04 & 0.19 & 0 & 1 \\
\hline
\end{tabular}


Table 2: Regression results: All students.

Dependent variable: Support for environmental protection.

Ordered probit with robust standard errors.

\begin{tabular}{|c|c|c|c|c|c|c|}
\hline & \multicolumn{5}{|c|}{ Coefficient estimates } & \multirow{2}{*}{$\frac{\text { Marginal effects }}{(6)}$} \\
\hline & $(1)$ & $(2)$ & (3) & (4) & (5) & \\
\hline Christian-conservative & $\begin{array}{c}-0.0437 * * * \\
(-9.60)\end{array}$ & $\begin{array}{c}-0.0415^{* * *} \\
(-8.93)\end{array}$ & $\begin{array}{c}-0.0400^{* * *} \\
(-8.57)\end{array}$ & $\begin{array}{c}-0.0382^{* * *} \\
(-8.04)\end{array}$ & $\begin{array}{c}-0.0525^{* * *} \\
(-8.70)\end{array}$ & $\begin{array}{c}-0.00200 * * * \\
(-7.64)\end{array}$ \\
\hline Market-oriented & $\begin{array}{c}-0.0260 * * * \\
(-5.49)\end{array}$ & $\begin{array}{c}-0.0238 * * * \\
(-4.90)\end{array}$ & $\begin{array}{c}-0.0248 * * * \\
(-5.11)\end{array}$ & $\begin{array}{c}-0.0225 * * * \\
(-4.55)\end{array}$ & $\begin{array}{c}-0.0219 * * * \\
(-3.57)\end{array}$ & $\begin{array}{c}-0.00118 * * * \\
(-4.47)\end{array}$ \\
\hline Social-democratic & $\begin{array}{c}-0.0146 * * * \\
(-2.71)\end{array}$ & $\begin{array}{c}-0.0127 * * \\
(-2.32)\end{array}$ & $\begin{array}{c}-0.0236^{* * *} \\
(-4.30)\end{array}$ & $\begin{array}{c}-0.0222 * * * \\
(-3.95)\end{array}$ & $\begin{array}{c}-0.0280 * * * \\
(-4.00)\end{array}$ & $\begin{array}{c}-0.00116 * * * \\
(-3.90)\end{array}$ \\
\hline Green & $\begin{array}{l}0.265 * * * \\
(52.32)\end{array}$ & $\begin{array}{c}0.257 * * * \\
(49.21)\end{array}$ & $\begin{array}{c}0.259 * * * \\
(50.12)\end{array}$ & $\begin{array}{c}0.253 * * * \\
(47.48)\end{array}$ & $\begin{array}{c}0.263 * * * \\
(39.67)\end{array}$ & $\begin{array}{l}0.0132 * * * \\
(19.62)\end{array}$ \\
\hline Female & & $\begin{array}{l}0.0344^{* *} \\
(2.41)\end{array}$ & & $\begin{array}{l}0.0351^{* *} \\
(2.37)\end{array}$ & $\begin{array}{l}0.0101 \\
(0.56)\end{array}$ & $\begin{array}{l}0.00180 * * \\
\quad(2.41)\end{array}$ \\
\hline Age & & $\begin{array}{c}0.00967 * * * \\
(2.85)\end{array}$ & & $\begin{array}{c}0.00822 * * \\
(2.38)\end{array}$ & $\begin{array}{c}0.00564 \\
(1.32)\end{array}$ & $\begin{array}{l}0.000431^{* *} \\
(2.37)\end{array}$ \\
\hline East Germany & & $\begin{array}{l}-0.161 * \\
(-1.82)\end{array}$ & & $\begin{array}{l}-0.115 \\
(-1.31)\end{array}$ & $\begin{array}{l}-0.143 \\
(-1.58)\end{array}$ & $\begin{array}{c}-0.00742 \\
(-1.10)\end{array}$ \\
\hline $\begin{array}{l}\text { Importance of } \\
\text { high income }\end{array}$ & & $\begin{array}{c}-0.0315 * * * \\
(-6.38)\end{array}$ & & $\begin{array}{c}-0.0333 * * * \\
(-6.53)\end{array}$ & $\begin{array}{c}-0.0174 * * * \\
(-2.70)\end{array}$ & $\begin{array}{c}-0.00174 * * * \\
(-6.25)\end{array}$ \\
\hline $\begin{array}{c}\text { Socio-economic } \\
\text { background }\end{array}$ & & $\begin{array}{c}-0.00343 \\
(-0.62)\end{array}$ & & $\begin{array}{c}-0.00730 \\
(-1.29)\end{array}$ & $\begin{array}{c}-0.00721 \\
(-1.04)\end{array}$ & $\begin{array}{c}-0.000383 \\
(-1.29)\end{array}$ \\
\hline $\begin{array}{l}\text { Importance of } \\
\text { religion and faith }\end{array}$ & & & & & $\begin{array}{c}0.0403^{* * *} \\
(8.75)\end{array}$ & \\
\hline $\begin{array}{l}\text { Internal locus of } \\
\text { control }\end{array}$ & & & $\begin{array}{c}-0.0211^{* * *} \\
(-4.94)\end{array}$ & $\begin{array}{c}-0.0155^{* * *} \\
(-3.53)\end{array}$ & $\begin{array}{c}-0.0128^{* *} \\
(-2.39)\end{array}$ & $\begin{array}{c}-0.000814^{* * * *} \\
(-3.48)\end{array}$ \\
\hline $\begin{array}{l}\text { Importance of politics } \\
\text { and public life }\end{array}$ & & & $\begin{array}{c}0.0721 * * * \\
(15.50)\end{array}$ & $\begin{array}{c}0.0736 * * * \\
(15.37)\end{array}$ & $\begin{array}{c}0.0560 * * * \\
(9.44)\end{array}$ & $\begin{array}{l}0.00386 * * * \\
\quad(12.60)\end{array}$ \\
\hline $\begin{array}{l}\text { Importance of social- } \\
\text { izing and friends }\end{array}$ & & & $\begin{array}{c}0.104^{* * *} \\
(15.49)\end{array}$ & $\begin{array}{c}0.104^{* * *} \\
(15.05)\end{array}$ & $\begin{array}{c}0.0946 * * * \\
(10.92)\end{array}$ & $\begin{array}{c}0.00543^{* * *} \\
(12.57)\end{array}$ \\
\hline Wave 2 & $\begin{array}{c}0.573 * * * \\
(23.86)\end{array}$ & $\begin{array}{c}0.564 * * * \\
(22.61)\end{array}$ & $\begin{array}{c}0.629 * * * \\
(25.45)\end{array}$ & $\begin{array}{c}0.615^{* * *} \\
(24.02)\end{array}$ & & $\begin{array}{c}-0.00710 * * * \\
(-3.09)\end{array}$ \\
\hline Wave 3 & $\begin{array}{l}0.592 * * * \\
(24.22)\end{array}$ & $\begin{array}{l}0.580 * * * \\
(22.92)\end{array}$ & $\begin{array}{c}0.653 * * * \\
(26.05)\end{array}$ & $\begin{array}{c}0.637 * * * \\
(24.57)\end{array}$ & & $\begin{array}{c}-0.00985 * * * \\
(-3.93)\end{array}$ \\
\hline Wave 4 & $\begin{array}{c}0.690 * * * \\
(26.69)\end{array}$ & $\begin{array}{c}0.682 * * * \\
(25.70)\end{array}$ & $\begin{array}{c}0.741^{* * *} \\
(27.82)\end{array}$ & $\begin{array}{c}0.728 * * * \\
(26.67)\end{array}$ & $\begin{array}{c}0.723 * * * \\
(26.10)\end{array}$ & $\begin{array}{c}-0.0218 * * * \\
(-6.62)\end{array}$ \\
\hline Wave 5 & $\begin{array}{c}0.654 * * * \\
(27.88)\end{array}$ & $\begin{array}{c}0.653 * * * \\
(26.98)\end{array}$ & $\begin{array}{c}0.707 * * * \\
(29.17)\end{array}$ & $\begin{array}{c}0.700 * * * \\
(28.02)\end{array}$ & $\begin{array}{c}0.693 * * * \\
(27.33)\end{array}$ & $\begin{array}{c}-0.0153 * * * \\
(-5.63)\end{array}$ \\
\hline Wave 6 & $\begin{array}{c}0.431^{* * *} \\
(16.90)\end{array}$ & $\begin{array}{c}0.423 * * * \\
(16.15)\end{array}$ & $\begin{array}{c}0.495^{* * *} \\
(18.89)\end{array}$ & $\begin{array}{c}0.485^{* * *} \\
(18.08)\end{array}$ & $\begin{array}{c}0.476^{* * *} \\
(17.50)\end{array}$ & $\begin{array}{c}-0.00445^{* *} \\
(-2.08)\end{array}$ \\
\hline Wave 7 & $\begin{array}{c}0.270 * * * \\
(10.40)\end{array}$ & $\begin{array}{c}0.267 * * * \\
(10.01)\end{array}$ & $\begin{array}{c}0.311^{* * *} \\
(11.63)\end{array}$ & $\begin{array}{c}0.305^{* * *} \\
(11.13)\end{array}$ & $\begin{array}{c}0.293 * * * \\
(10.67)\end{array}$ & $\begin{array}{c}0.00390^{* * *} \\
(3.81)\end{array}$ \\
\hline Fixed university effects & Yes & Yes & Yes & Yes & Yes & Yes \\
\hline Observations & 28,550 & 27,653 & 27,654 & 26,839 & 17,643 & 26,839 \\
\hline
\end{tabular}

Reference category of the wave dummy variables is wave 9. Column (6) describes marginal effects when support for environment protection assumes the value 6 ("agree with being characterized as a supporter of environmental protection”);

$t$-statistics in parentheses; * $p<0.10, * * p<0.05, * * * p<0.01$ 
Table 3: Regression results: Partisan students.

Dependent variable: Support for environmental protection.

Ordered probit with robust standard errors.

\begin{tabular}{|c|c|c|c|c|c|c|}
\hline & \multicolumn{5}{|c|}{ Coefficient estimates } & \multirow{2}{*}{$\frac{\text { Marginal effects }}{(6)}$} \\
\hline & (1) & (2) & (3) & (4) & (5) & \\
\hline Christian-conservative & $\begin{array}{c}-0.0492^{* * *} \\
(-7.24)\end{array}$ & $\begin{array}{c}-0.0470^{* * *} \\
(-6.78)\end{array}$ & $\begin{array}{c}-0.0408^{* * *} \\
(-5.80)\end{array}$ & $\begin{array}{c}-0.0395 * * * \\
(-5.53)\end{array}$ & $\begin{array}{c}-0.0483^{* * *} \\
(-5.17)\end{array}$ & $\begin{array}{c}-0.00178^{* * *} \\
(-5.17)\end{array}$ \\
\hline Market-oriented & $\begin{array}{c}-0.0367 * * * \\
(-5.34)\end{array}$ & $\begin{array}{c}-0.0328 * * * \\
(-4.64)\end{array}$ & $\begin{array}{c}-0.0302 * * * \\
(-4.30)\end{array}$ & $\begin{array}{c}-0.0267 * * * \\
(-3.71)\end{array}$ & $\begin{array}{c}-0.0232 * * \\
(-2.52)\end{array}$ & $\begin{array}{c}-0.00120 * * * \\
(-3.61)\end{array}$ \\
\hline Social-democratic & $\begin{array}{c}-0.0390 * * * \\
(-5.04)\end{array}$ & $\begin{array}{c}-0.0379 * * * \\
(-4.78)\end{array}$ & $\begin{array}{c}-0.0423^{* * *} \\
(-5.38)\end{array}$ & $\begin{array}{c}-0.0422^{* * *} \\
(-5.23)\end{array}$ & $\begin{array}{c}-0.0451^{* * *} \\
(-4.30)\end{array}$ & $\begin{array}{c}-0.00190 * * * \\
(-4.95)\end{array}$ \\
\hline Green & $\begin{array}{c}0.263 * * * \\
(34.60)\end{array}$ & $\begin{array}{c}0.255^{* * * *} \\
(32.52)\end{array}$ & $\begin{array}{c}0.262 * * * \\
(33.63)\end{array}$ & $\begin{array}{c}0.255 * * * \\
(31.90)\end{array}$ & $\begin{array}{c}0.264 * * * \\
(25.74)\end{array}$ & $\begin{array}{l}0.0115 * * * \\
(11.79)\end{array}$ \\
\hline Female & & $\begin{array}{l}0.0249 \\
(1.18)\end{array}$ & & $\begin{array}{c}0.0185 \\
(0.84)\end{array}$ & $\begin{array}{c}-0.0154 \\
(-0.56)\end{array}$ & $\begin{array}{c}0.000820 \\
(0.85)\end{array}$ \\
\hline Age & & $\begin{array}{c}0.00791 \\
(1.59)\end{array}$ & & $\begin{array}{c}0.00704 \\
(1.39)\end{array}$ & $\begin{array}{c}0.00258 \\
(0.40)\end{array}$ & $\begin{array}{l}0.000317 \\
(1.38)\end{array}$ \\
\hline East Germany & & $\begin{array}{l}-0.165 \\
(-1.10)\end{array}$ & & $\begin{array}{l}-0.139 \\
(-0.92)\end{array}$ & $\begin{array}{l}-0.189 \\
(-1.23)\end{array}$ & $\begin{array}{c}-0.00835 \\
(-0.73)\end{array}$ \\
\hline $\begin{array}{l}\text { Importance of } \\
\text { high income }\end{array}$ & & $\begin{array}{c}-0.0304 * * * \\
(-4.22)\end{array}$ & & $\begin{array}{c}-0.0302^{* * *} \\
(-4.08)\end{array}$ & $\begin{array}{c}-0.0206^{* *} \\
(-2.13)\end{array}$ & $\begin{array}{c}-0.00136 * * * \\
(-3.88)\end{array}$ \\
\hline $\begin{array}{c}\text { Socio-economic } \\
\text { background }\end{array}$ & & $\begin{array}{c}-0.00870 \\
(-1.07)\end{array}$ & & $\begin{array}{c}-0.0109 \\
(-1.33)\end{array}$ & $\begin{array}{c}-0.00648 \\
(-0.62)\end{array}$ & $\begin{array}{c}-0.000492 \\
(-1.32)\end{array}$ \\
\hline $\begin{array}{l}\text { Importance of } \\
\text { religion and faith }\end{array}$ & & & & & $\begin{array}{c}0.0345 * * * \\
(5.02)\end{array}$ & \\
\hline $\begin{array}{l}\text { Internal locus of } \\
\text { control }\end{array}$ & & & $\begin{array}{c}-0.0228 * * * \\
(-3.58)\end{array}$ & $\begin{array}{c}-0.0181^{* * * *} \\
(-2.75)\end{array}$ & $\begin{array}{c}-0.0132 \\
(-1.59)\end{array}$ & $\begin{array}{c}-0.000815^{* * * *} \\
(-2.68)\end{array}$ \\
\hline $\begin{array}{l}\text { Importance of politics } \\
\text { and public life }\end{array}$ & & & $\begin{array}{l}0.0683 * * * \\
(9.82)\end{array}$ & $\begin{array}{c}0.0688 * * * \\
(9.61)\end{array}$ & $\begin{array}{c}0.0457 * * * \\
(5.01)\end{array}$ & $\begin{array}{c}0.00309 * * * \\
(7.62)\end{array}$ \\
\hline $\begin{array}{l}\text { Importance of social- } \\
\text { izing and friends }\end{array}$ & & & $\begin{array}{c}0.104 * * * \\
(10.49)\end{array}$ & $\begin{array}{c}0.103 * * * \\
(10.20)\end{array}$ & $\begin{array}{c}0.0900 * * * \\
(6.90)\end{array}$ & $\begin{array}{c}0.00466^{* * * *} \\
(8.09)\end{array}$ \\
\hline Wave 2 & $\begin{array}{c}0.601 * * * \\
(16.96)\end{array}$ & $\begin{array}{c}0.593 * * * \\
(16.13)\end{array}$ & $\begin{array}{c}0.656 * * * \\
(18.02)\end{array}$ & $\begin{array}{c}0.641^{* * *} \\
(17.04)\end{array}$ & & $\begin{array}{c}-0.0118 * * * \\
(-3.28)\end{array}$ \\
\hline Wave 3 & $\begin{array}{c}0.583 * * * \\
(16.18)\end{array}$ & $\begin{array}{c}0.570 * * * \\
(15.33)\end{array}$ & $\begin{array}{c}0.652 * * * \\
(17.63)\end{array}$ & $\begin{array}{c}0.635^{* * *} \\
(16.65)\end{array}$ & & $\begin{array}{c}-0.0120 * * * \\
(-3.26)\end{array}$ \\
\hline Wave 4 & $\begin{array}{c}0.724 * * * \\
(18.55)\end{array}$ & $\begin{array}{c}0.716 * * * \\
(17.88)\end{array}$ & $\begin{array}{c}0.776 * * * \\
(19.33)\end{array}$ & $\begin{array}{c}0.760 * * * \\
(18.50)\end{array}$ & $\begin{array}{c}0.759 * * * \\
(18.15)\end{array}$ & $\begin{array}{c}-0.0310 * * * \\
(-5.71)\end{array}$ \\
\hline Wave 5 & $\begin{array}{c}0.666 * * * \\
(18.79)\end{array}$ & $\begin{array}{c}0.658 * * * \\
(18.02)\end{array}$ & $\begin{array}{c}0.716 * * * \\
(19.51)\end{array}$ & $\begin{array}{c}0.700^{* * *} \\
(18.55)\end{array}$ & $\begin{array}{c}0.699 * * * \\
(18.18)\end{array}$ & $\begin{array}{c}-0.0219 * * * \\
(-4.95)\end{array}$ \\
\hline Wave 6 & $\begin{array}{c}0.433 * * * \\
(11.30)\end{array}$ & $\begin{array}{c}0.416 * * * \\
(10.61)\end{array}$ & $\begin{array}{c}0.493 * * * \\
(12.53)\end{array}$ & $\begin{array}{c}0.474 * * * \\
(11.79)\end{array}$ & $\begin{array}{c}0.468 * * * \\
(11.48)\end{array}$ & $\begin{array}{c}-0.00715^{* *} \\
(-2.14)\end{array}$ \\
\hline Wave 7 & $\begin{array}{c}0.282^{* * *} \\
(7.00)\end{array}$ & $\begin{array}{c}0.268 * * * \\
(6.49)\end{array}$ & $\begin{array}{c}0.310 * * * \\
(7.49)\end{array}$ & $\begin{array}{c}0.293 * * * \\
(6.91)\end{array}$ & $\begin{array}{c}0.282 * * * \\
(6.61)\end{array}$ & $\begin{array}{c}0.00171 \\
(0.98)\end{array}$ \\
\hline Fixed university effects & Yes & Yes & Yes & Yes & Yes & Yes \\
\hline Observations & 13,231 & 12,843 & 12,849 & 12,497 & 7,777 & 12,497 \\
\hline
\end{tabular}

Reference category of the wave dummy variables is wave 9. Column (6) describes marginal effects when support for environment protection assumes the value 6 ("agree with being characterized as a supporter of environmental protection”);

$t$-statistics in parentheses; ** $p<0.05, * * * p<0.01$ 
Table 4: Regression results: Separate for the four types of partisans.

Dependent variable: Support for environmental protection.

Ordered probit with robust standard errors. Coefficient estimates.

\begin{tabular}{lcccc}
\hline & $\begin{array}{c}\text { Christian- } \\
\text { conservative }\end{array}$ & $\begin{array}{c}\text { Market- } \\
\text { oriented }\end{array}$ & $\begin{array}{c}\text { Social- } \\
\text { democratic }\end{array}$ & Green \\
\hline Female & $(1)$ & $(2)$ & $(3)$ & $(4)$ \\
Age & -0.0168 & $0.123^{* *}$ & $0.0953^{* *}$ & 0.0352 \\
& $(-0.36)$ & $(2.11)$ & $(2.26)$ & $(0.93)$ \\
East Germany & $0.0176^{*}$ & -0.00108 & 0.0134 & 0.0137 \\
& $(1.74)$ & $(-0.08)$ & $(1.37)$ & $(1.58)$ \\
Importance of high income & -0.256 & 0.363 & -0.376 & -0.397 \\
& $(-0.79)$ & $(0.97)$ & $(-1.31)$ & $(-1.32)$ \\
Socio-economic background & $-0.0423^{* * *}$ & $-0.0511^{* *}$ & $-0.0261^{*}$ & $-0.0449^{* * *}$ \\
& $(-2.69)$ & $(-2.54)$ & $(-1.82)$ & $(-3.65)$ \\
Internal locus of control & $-0.0350^{* *}$ & $-0.0377^{*}$ & 0.00830 & -0.0168 \\
& $(-2.07)$ & $(-1.88)$ & $(0.52)$ & $(-1.15)$ \\
Importance of politics and public life & $-0.0374^{* * *}$ & $-0.0602^{* * *}$ & -0.00940 & $-0.0318^{* * *}$ \\
& $(-2.64)$ & $(-3.38)$ & $(-0.77)$ & $(-2.91)$ \\
Importance of socializing and friends & $0.0508^{* * *}$ & $0.0340^{*}$ & $0.0893^{* * *}$ & $0.0831^{* * *}$ \\
& $(3.33)$ & $(1.91)$ & $(6.28)$ & $(6.84)$ \\
\hline Fixed wave effects & $0.151^{* * *}$ & $0.116^{* * *}$ & $0.0973^{* * *}$ & $0.0941^{* * *}$ \\
\hline Fixed university effects & $(7.16)$ & $(4.99)$ & $(5.04)$ & $(5.02)$ \\
\hline Observations & Yes & Yes & Yes & Yes \\
\hline t-statistics in parentheses; $p<0.10 * * *<05$ & Yes & Yes \\
\hline
\end{tabular}

$t$-statistics in parentheses; $* p<0.10,{ }^{* *} p<0.05, * * * p<0.01$

Table 5: Regression results: Alternative dependent variables.

Ordered probit with robust standard errors. Coefficient estimates.

\begin{tabular}{|c|c|c|c|c|c|c|c|c|c|}
\hline & \multicolumn{3}{|c|}{ All students } & \multicolumn{3}{|c|}{ Partisan students } & \multicolumn{3}{|c|}{$\begin{array}{c}\text { Separate for the } \\
\text { four types of partisans }\end{array}$} \\
\hline & Priority & $\begin{array}{l}\text { Increased } \\
\text { utilization }\end{array}$ & Shutdown & Priority & $\begin{array}{l}\text { Increased } \\
\text { utilization }\end{array}$ & Shutdown & $\begin{array}{l}\text { Priority } \\
\text { C M S G }\end{array}$ & $\begin{array}{c}\text { Increased } \\
\text { utilization } \\
\text { C M S G }\end{array}$ & $\begin{array}{l}\text { Shutdown } \\
\text { C M S G }\end{array}$ \\
\hline $\begin{array}{l}\text { Internal } \\
\text { locus of } \\
\text { control }\end{array}$ & $\begin{array}{c}-0.0380 \\
* * * \\
(9.58) \\
\end{array}$ & $\begin{array}{c}0.0635 \\
* * * \\
(9.07) \\
\end{array}$ & $\begin{array}{c}-0.0278 \\
* * * \\
(5.82) \\
\end{array}$ & $\begin{array}{c}-0.0428 \\
* * * \\
(7.15)\end{array}$ & $\begin{array}{c}0.0653 \\
* * * \\
(6.49)\end{array}$ & $\begin{array}{c}-0.0254 \\
* * * \\
(3.42) \\
\end{array}$ & ---- & ++++ & $-(-)--$ \\
\hline $\begin{array}{l}\text { Imp. of } \\
\text { socializing } \\
\text { \& friends }\end{array}$ & $\begin{array}{c}0.0881 \\
* * * \\
(14.27)\end{array}$ & $\begin{array}{c}-0.0465 \\
* * * \\
(4.68)\end{array}$ & $\begin{array}{c}0.0397 \\
* * * \\
(5.13) \\
\end{array}$ & $\begin{array}{c}0.0847 \\
* * * \\
(9.35)\end{array}$ & $\begin{array}{c}-0.0365 \\
* * * \\
(2.60) \\
\end{array}$ & $\begin{array}{c}0.0413 \\
* * * \\
(3.41)\end{array}$ & ++++ & $-(--)-$ & $+(+)++$ \\
\hline $\begin{array}{l}\text { Imp. of } \\
\text { politics \& } \\
\text { public life }\end{array}$ & $\begin{array}{c}0.00217 \\
(0.52)\end{array}$ & $\begin{array}{c}-0.0830 \\
* * * \\
(11.40)\end{array}$ & $\begin{array}{c}0.0573 \\
* * * \\
(11.14)\end{array}$ & $\begin{array}{r}-0.00344 \\
(0.54)\end{array}$ & $\begin{array}{c}-0.0786 \\
* * * \\
(7.38)\end{array}$ & $\begin{array}{c}0.0656 \\
* * * \\
(8.18)\end{array}$ & $--+(+)$ & $+(-)--$ & $(-)+++$ \\
\hline
\end{tabular}

C: Christian-conservative, M: Market-oriented, S: Social-democratic, G: Green;

(.): not statistically significant;

$t$-statistics in parentheses; $* * * p<0.01$ 
Figure 1: Determinants of support for environment protection policies.

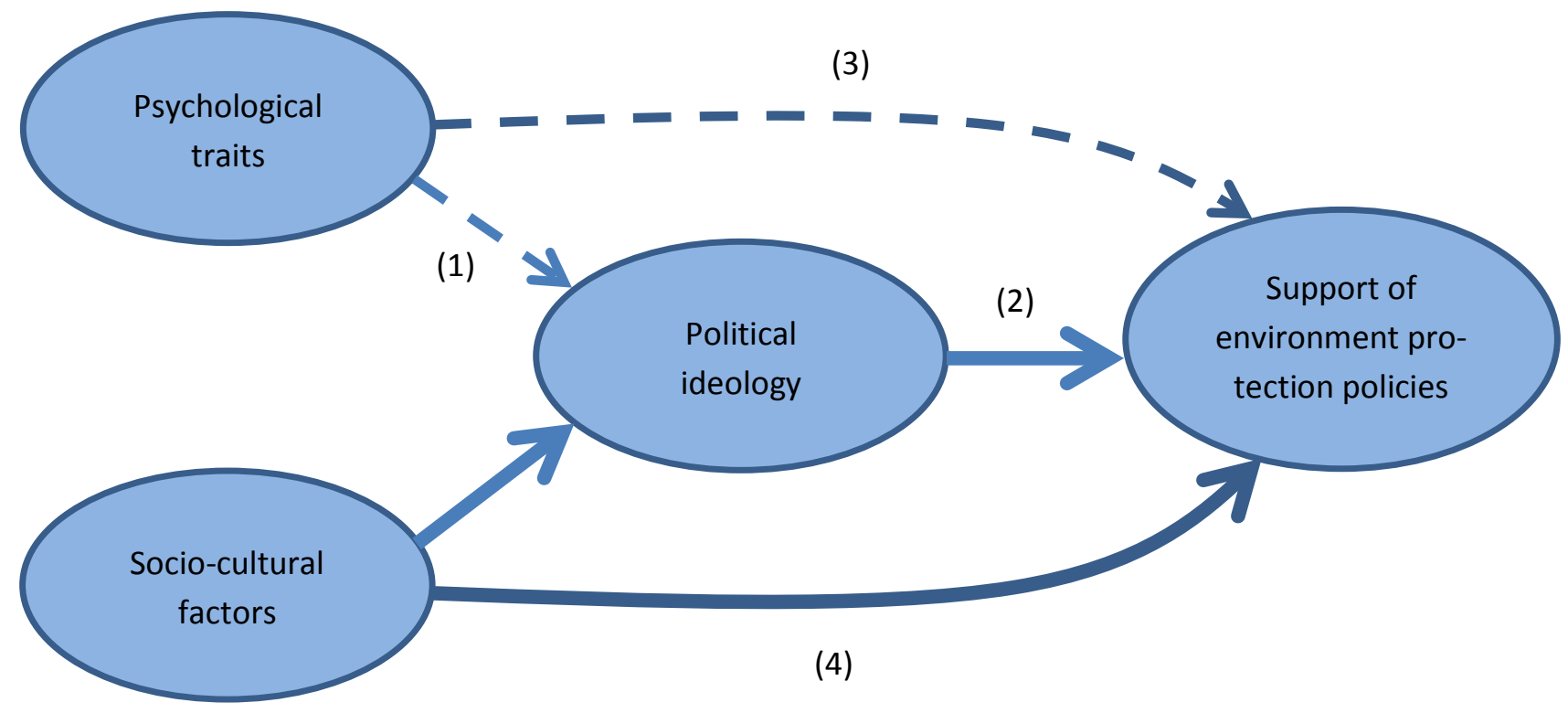

Traditional political-economic mechanisms

-2 Behavioral mechanisms 
Figure 2a: Support for environmental protection and gender.

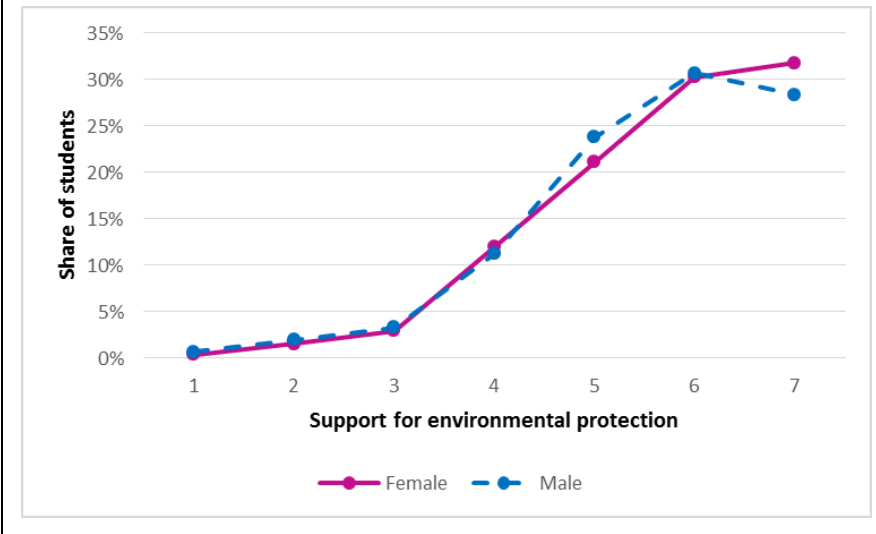

Figure 2b: Support for environmental protection and political attitudes.

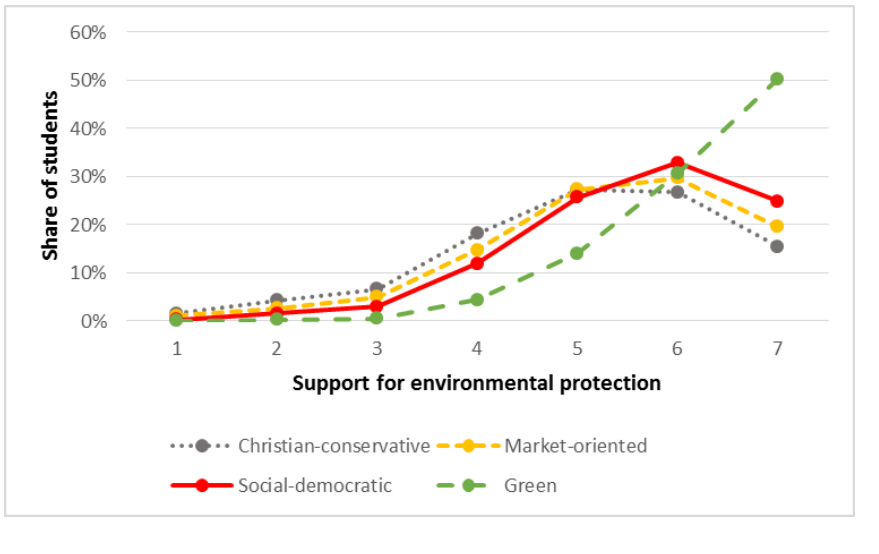

Figure 3: Support for environmental protection and internal locus of control / expressiveness.

3a: Support for environmental protection and importance of religion and faith.

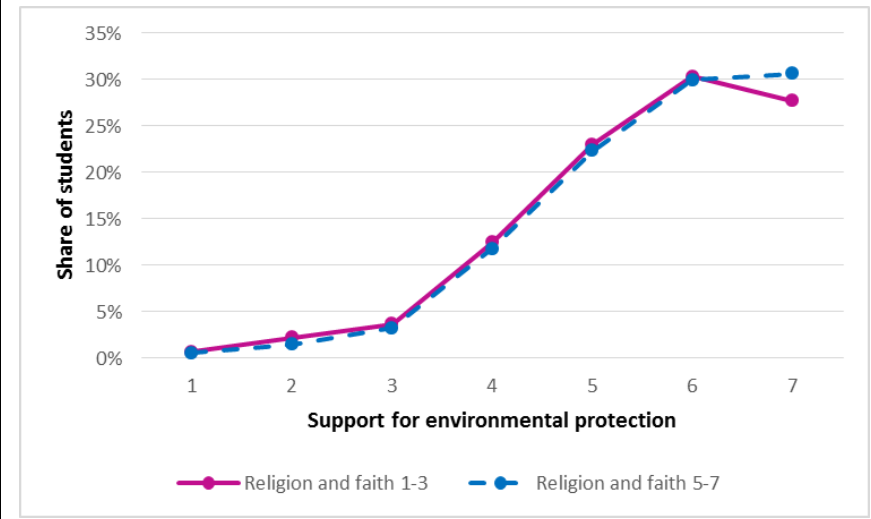

3c: Support for environmental protection and importance of politics and public life.

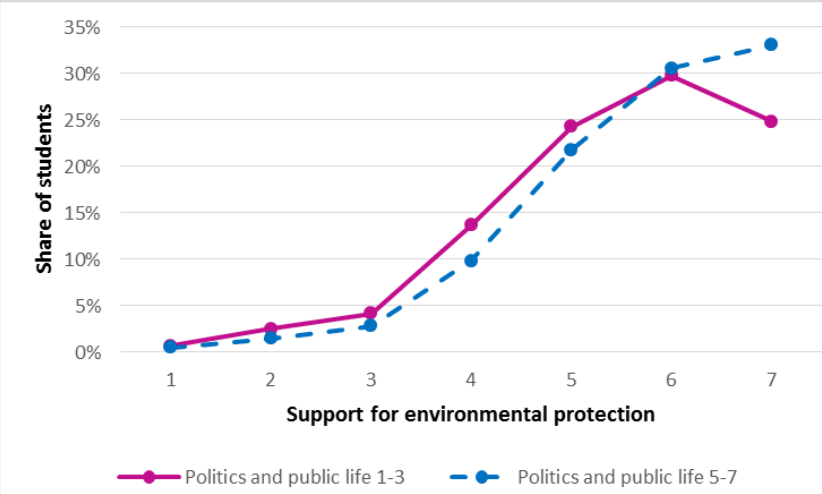

3b: Support for environmental protection and internal locus of control.

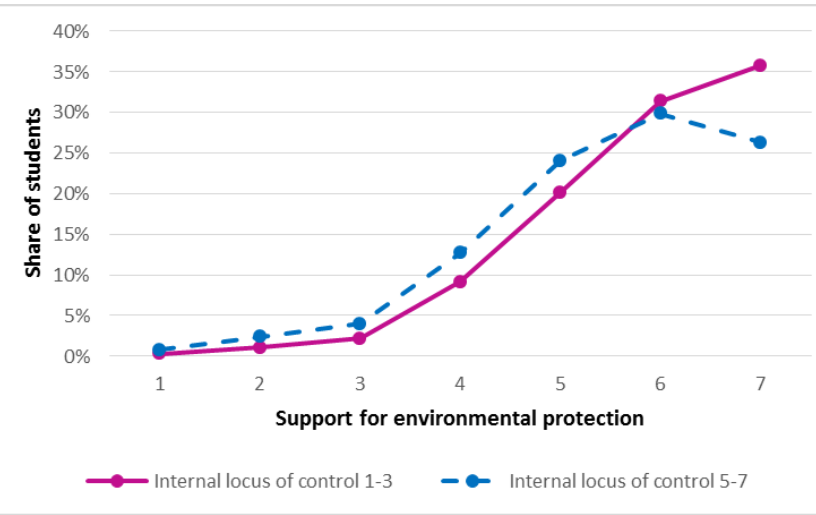

3d: Support for environmental protection and importance of socializing and friends.

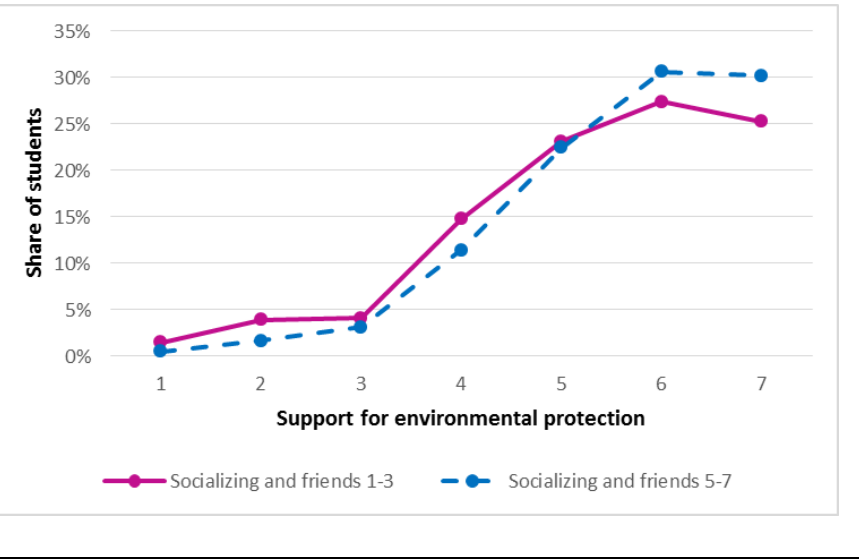


Figure 4: Internal locus of control / expressiveness variables and partisan students.

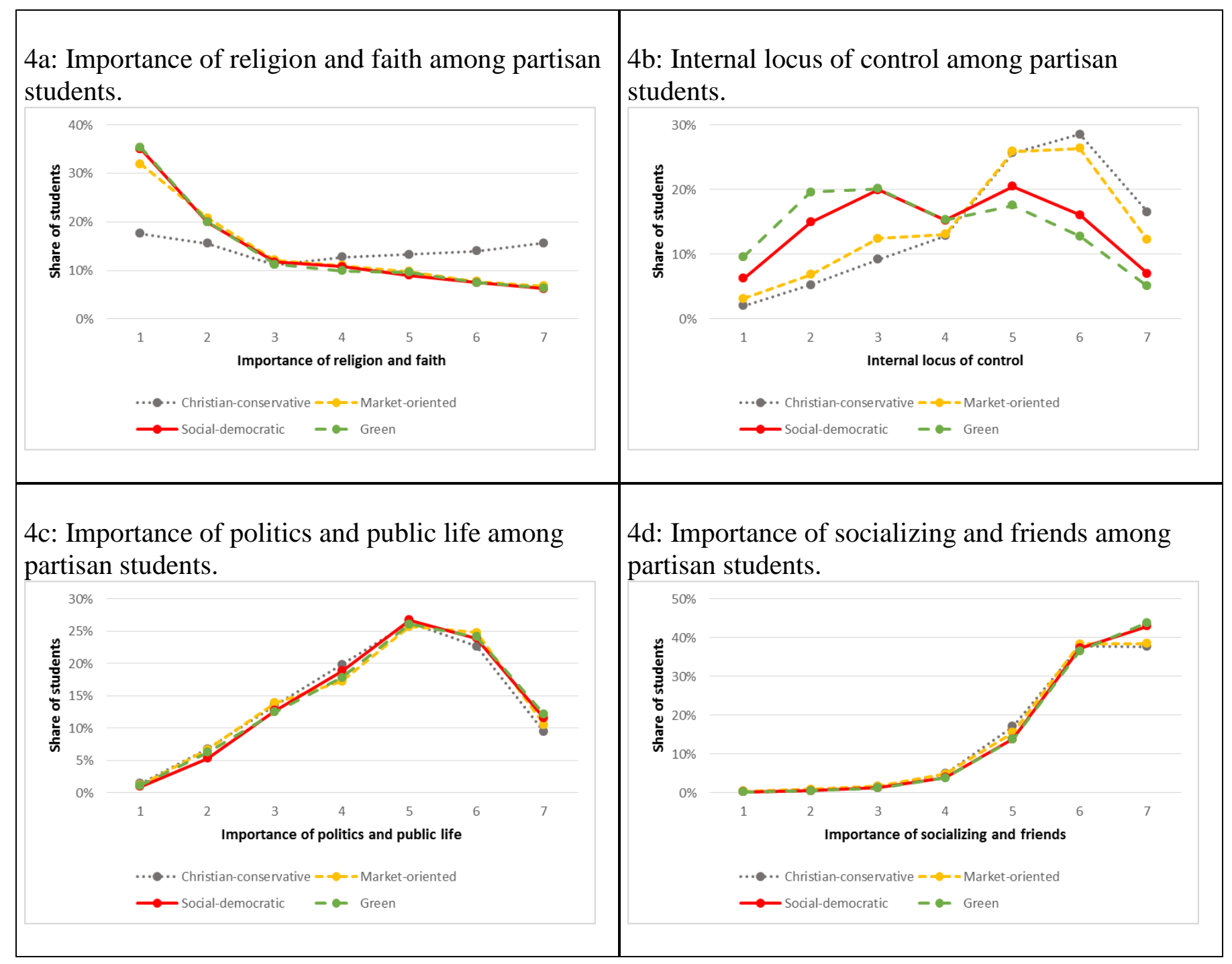




\section{Appendix}

Table A1: Support of environmental protection: political attitudes and personality indicators.

Support of environmental protection

(mean values; 1: do not agree at all, 7: fully agree)

dependent on political attitudes

sample

and personality indicators

(1: do not agree at all, 7: fully agree)

\begin{tabular}{|c|c|c|c|c|c|c|c|c|}
\hline & (1) & $(2)$ & $(3)$ & (4) & (5) & (6) & $(7)$ & \\
\hline Christian-conservative & 6.06 & 5.92 & 5.72 & 5.59 & 5.43 & 5.18 & 4.86 & All \\
\hline Market-oriented & 5.96 & 5.91 & 5.76 & 5.63 & 5.56 & 5.43 & 5.30 & \\
\hline Social-democratic & 5.19 & 5.25 & 5.38 & 5.55 & 5.74 & 5.83 & 5.90 & \\
\hline Green & 4.56 & 4.96 & 5.26 & 5.44 & 5.76 & 6.15 & 6.52 & \\
\hline Importance of religion and faith & 5.56 & 5.56 & 5.60 & 5.59 & 5.63 & 5.67 & 5.69 & \\
\hline Internal locus of control & 6.04 & 5.91 & 5.74 & 5.58 & 5.52 & 5.51 & 5.49 & \\
\hline Importance of politics and public life & 5.31 & 5.45 & 5.50 & 5.56 & 5.67 & 5.76 & 5.95 & \\
\hline Importance of socializing and friends & 5.25 & 5.22 & 5.46 & 5.42 & 5.48 & 5.62 & 5.78 & \\
\hline Christian-conservative & 6.09 & 5.93 & 5.76 & 5.59 & 5.45 & 5.17 & 4.71 & Females \\
\hline Market-oriented & 6.01 & 5.95 & 5.75 & 5.66 & 5.60 & 5.54 & 5.50 & \\
\hline Social-democratic & 5.30 & 5.36 & 5.54 & 5.58 & 5.76 & 5.83 & 5.92 & \\
\hline Green & 4.55 & 4.84 & 5.23 & 5.36 & 5.75 & 6.13 & 6.54 & \\
\hline Importance of religion and faith & 5.62 & 5.62 & 5.61 & 5.54 & 5.70 & 5.71 & 5.67 & \\
\hline Internal locus of control & 6.08 & 5.95 & 5.73 & 5.59 & 5.56 & 5.56 & 5.58 & \\
\hline Importance of politics and public life & 5.49 & 5.50 & 5.55 & 5.61 & 5.74 & 5.89 & 6.03 & \\
\hline Importance of socializing and friends & 5.20 & 5.00 & 5.76 & 5.44 & 5.60 & 5.64 & 5.79 & \\
\hline Christian-conservative & 6.04 & 5.92 & 5.70 & 5.59 & 5.42 & 5.18 & 4.92 & Males \\
\hline Market-oriented & 5.93 & 5.87 & 5.76 & 5.61 & 5.53 & 5.38 & 5.23 & \\
\hline Social-democratic & 5.14 & 5.18 & 5.31 & 5.53 & 5.73 & 5.82 & 5.89 & \\
\hline Green & 4.57 & 5.01 & 5.27 & 5.49 & 5.77 & 6.17 & 6.50 & \\
\hline Importance of religion and faith & 5.52 & 5.51 & 5.60 & 5.64 & 5.57 & 5.64 & 5.72 & \\
\hline Internal locus of control & 6.00 & 5.87 & 5.74 & 5.58 & 5.51 & 5.49 & 5.45 & \\
\hline Importance of politics and public life & 5.18 & 5.41 & 5.46 & 5.52 & 5.62 & 5.70 & 5.92 & \\
\hline Importance of socializing and friends & 5.27 & 5.31 & 5.36 & 5.42 & 5.42 & 5.61 & 5.77 & \\
\hline
\end{tabular}


Figure A1: Socio-economic background of partisan students.

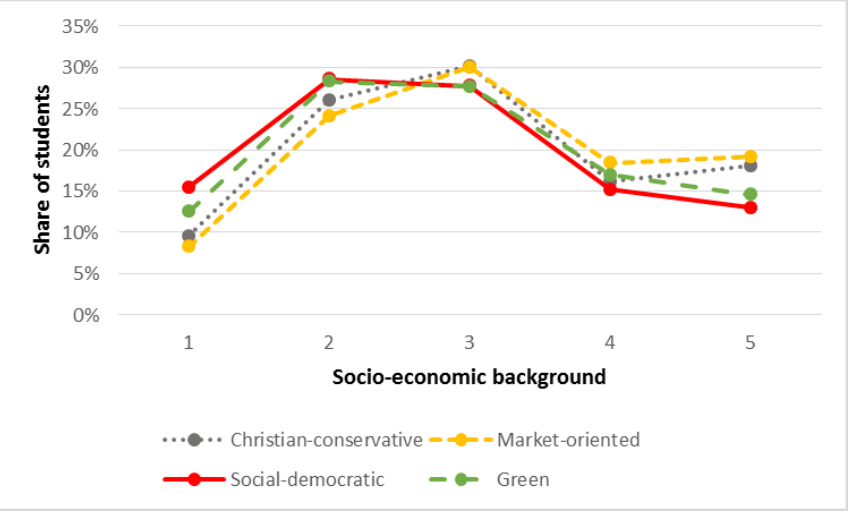

